Article

\title{
Innate Intuition: An Intellectual History of Sahaja-jūāna and Sahaja Samādhi in Brahmoism and Modern Vaișnavism
}

\author{
Abhishek Ghosh \\ Religious Studies Program, Department of Integrative, Religious, and Intercultural Studies (IRIS), \\ Grand Valley State University, Allendale, MI 49401, USA; ghoshab@gvsu.edu
}

Received: 20 May 2019; Accepted: 3 June 2019; Published: 14 June 2019

\begin{abstract}
This article is about sahaja-jñāna, or 'innate intuition', as a form of Brahmo and Vaiṣnava epistemology $-a$ foundational invention within the development of modern Hinduism. I examine its nineteenth-century intellectual history in Bengal in the works of the Vaisnava theologian Kedarnath Datta Bhaktivinoda (1838-1914) and trace it back to two of his contemporaries, Keshub Chandra Sen (1838-1884) and a senior leader of the Brahmo Samaj whom they both knew, Debendranath Tagore (1817-1905). This relatively understudied yet epistemologically significant term within modern Hinduism has its roots in the pre-colonial sahajiy $\bar{a}$ movements and bears a conceptual resemblance to the idea of pratibha in ancient Indian aesthetics, philosophy, and grammar. The idea of sahaja is key among the sahajiyā Vaișnavas, a so-called heterodox group that Western-educated, middle-class Bengali bhadraloks, including Bhaktivinoda, vehemently disassociated themselves from due to the social stigma attached to its sexo-yogic practices. Furthermore, I argue that Bhaktivinoda's concept of sahaja-jñāna departs significantly from both sahajiyā and Brahmo versions of sahaja-jñāna and represents an innovation within the ambit of Vaiṣnava Vedanta, which accepts verbal testimony (śabda or śāstra) as the only valid form of epistemology. In documenting the intellectual history of a significant idea, I contend that the bhadralok Bengali Vaiṣnava leaders arrogate, desexualize, and Vedānticize a term as a form of experimentation during the construction of modern Hinduism.
\end{abstract}

Keywords: Bhaktivinoda; sahaja-jñāna; Gauḍiya Vaiṣnavism; Brahmo Samaj; modern Hinduism; nineteenth-century Bengal; intuition; epistemology

\section{Introduction}

In colloquial Bengali parlance, the word sahaja means 'simple' or 'easy' (Biswas 2004); however, its use as a religious term, dating back to the eighth century, has been anything but simple. Sahaja has become a key religious term that not only encompasses the semantic scope of the common Bengali (or Sanskrit) usage, but also indicates complex ritual, epistemology, and the imagination of the nature of divinity itself within certain Hindu and Buddhist religious communities. The history of its usage spans Vajrayāna Buddhism in the eighth century, Nāth traditions from the eleventh century, Gaudīya Vaiṣnavism in the fifteenth century, and the Brahmo movement from the late nineteenth century onward. While these traditions continue to use the word in their religious terminology, each usage means something different. ${ }^{1}$ For many of these traditions, sahaja has a connotation based on its

1 Since my paper is mostly focused on Eastern India (Bengal, Orissa), I have not addressed a genealogy of sahaja in the broader South Asian context such as the Sant or Sikh tradition's understanding of the term found in the works of individuals like Kabir, Guru Nanak among others, and limit myself to traditions directly relevant to Bengali sahajiyāism. 
etymology in Sanskrit, saha-ja: 'co-born' or 'self-born' (depending on context), implying 'intuitive', 'innate', or 'natural'. Sahaja is something that is spontaneously innate and intuitive to every living being, like breathing, and therefore it is simple and easy-except, very often it is not, if we dive deeper into its meaning. The practitioners of the sahaja path—called sahajiyas -would say that it is complex in its simplicity. The religious practices and experiences that lie ahead for the practitioner are not necessarily difficult, but need to be esoteric, as not everyone can handle the erotic nature of their sexo-yogic practices.

I argue that the word sahaja became a significant descriptor of a form of epistemology, bearing testimony to the experimentation and innovation that characterized the birth of modern Hinduism in nineteenth-century Bengal. In that context, the entire term has been desexualized and 'Vedānticized' which is reflective of the turn Hinduism took in its encounter with colonial modernity. Sahaja was no longer something that needed to be secretive, but rather it was so simple and obvious that it was hidden in plain sight, waiting for us to be reminded of it. Thus, there is a clear shift in what the word meant to sahajiyā practitioners before the Brahmo movement appropriated and interpreted the term its own way.

Sahaja assumed a life of its own, particularly when it came to modern Hinduism's experimentation with social norms and new ideas during the so-called Bengali Renaissance, and this article approaches the intellectual history of sahaja-jñana, or 'innate intuition', as a key concept in the epistemological experimentation of modern Brahmoism and Vaiṣnavism. I analyze this process of desexualization through a discussion of three key thinkers who use the word sahaja, either principally or indirectly, in order to describe their spiritual precept without any reference to sexuality. The first among these seminal thinkers is Debendranath Tagore, father of the famed poet Rabindranath Tagore. He was also the founder of the Tattvabodini Sabha, which later merged with the Brahmo Sabha to become the Brahmo Samaj. Aside from this institutional contribution, Tagore can also be considered a key thinker in modern Bengal who reinterpreted the idea of sahaja in a novel way. Both he and one of the important figures he mentored, Keshub Sen, remain underrated players in the intellectual history of modern Hinduism, given the ways their contributions precipitated some of the most important institutions and worldviews of modern Hinduism.

For the purposes of this article, the last key thinker I draw on is Kedarnath Datta Bhaktivinoda, a friend of Tagore's eldest son, Dwijendranath Tagore (1840-1926), and Sen's classmate. Bhaktivinoda was one of the most prolific Bengali authors on Vaișnavism and a deputy magistrate in the British government. Sen and Bhaktivinoda were born in the same year and attended the same school; in their adulthood, Sen became a leader of the Brāhmo Samaj and Kedarnath Bhaktivinoda emerged as a prominent Gaudīya Vaiṣnava theologian and guru. In his works, Sen began to articulate sahaja-jñāna, which is parallel to his other concept, Jivana-Veda (literally, 'the Veda of Life'), which indicates that everyday life experiences are a direct confirmation of Vedantic ideas of the self, existence and the divine. Bhaktivinoda, on the other hand, stressed the textual hermeneutics of his Gaudīya Vaisnava tradition and was deeply committed to the canons of pre-colonial Vaisnavism. In their works, both used the term sahaja-jīñna, meaning 'innate intuition' or 'simple wisdom', which they claimed was within each living being. The term, however, did not originate with them and traces back to pre-colonial Vaiṣnava (and much earlier Buddhist) tantric sahaja-sädhana. The practitioners of this were known as sahajiyās too.

Through a discussion of the above three individuals, I will construct a mini-biography of the word sahaja in its nineteenth-century Hindu context, and briefly revisit its past in the pre-colonial era in order to provide historical context. The journey of the term in its modern Hindu-or, to be more precise, Brahmo and Vaiṣnava - context begins with Tagore. As we shall see later in the article, Tagore started his intellectual career with a deep sense of reverence toward the Upanisads at a time when Brahmoism began to prosper in Bengal. Only after a period of growth and expansion, as the Samaj started showing signs of teething under his leadership, did he feel that his followers needed a theological foundation. At this juncture, he studied the Upanishads more deeply, encountering 
sections that sounded 'regressive' compared to the 'progressive', rationalist stance that his movement began to take under Sen and Akshay Datta (1820-1886). At this point in his growth as a theologian, and in the Brahmo Samaj's growth as a religious movement, Tagore affirmed the key status of the terms ātma-pratyaya, and later sahaja-jñāna. Sahaja-jñāna or 'innate intuition' was confirmed not only as a simple form of spirituality, but also as the de facto epistemology of the Brahmo Samaj. In this, Tagore relinquished his long-held belief in the sanctity of sacred texts and took recourse to intuition.

This paper examines the ideas of sahaja-jñanna and sahaja-samādhi (innate state said to be the highest state of yoga) in Bengali Vaiṣnavism, particularly in reference to three texts authored by Bhaktivinoda: Datta Kaustubha (1873), Kṛșna Samhitā (1880), and Tattvaviveka vā Saccidānandanubhutih (1893). Bhaktivinoda was one of the most influential thinkers and prolific writers on Gaudiya Vaisnavism in the colonial period, and while he critiqued the tantric practices of sahajiyās much like his urban, Western-educated bhadralok colleagues, he nevertheless reclaimed some of its terminology, as had the Brahmos. These texts are especially relevant because they are the first in which we see an urban Bengali Vaiṣnava leader significantly depart from the norm of his pre-colonial predecessors, not only in terms of epistemology, but also with respect to the interlocutors of Vaisnava discourse.

\section{Sahajiyā-Shaming in Colonial Bengal}

Beginning with the core word sahaja, a web of related terms has been coined according to the needs of religious practitioners. Whether it was Hindu or Buddhist Sahajiyā tradition, the adjective sahajiy $\bar{a}$ referred to the practitioner, or sometimes even the nature of the practice itself; adherents also employed the words sahaja-sādhana (the process of spiritual practice), sahaja-dharma (the religion of sahaja), sahaja-ānanda (simple/innate bliss), and sahaja-samādhi (a state of intuitive rapture or trance). The Monier-Williams Sanskrit dictionary (Williams 1979) defines sahaja as 'born or produced together or at the same time', 'congenital', 'innate', 'hereditary', 'original', and 'natural' (i.e., by birth, by 'nature', 'naturally') and there may be other words derived from the basic term sahaja depending on context. This semantic field stretches to include a tantric teacher as well as God itself, while also encompassing the process of emancipation from human suffering.

Within any Indic philosophical or religious tradition, whether they are dharmic, tantric, or a blend of the two, the aim always remains liberation from human suffering-though prescribed paths to freedom may wildly differ. Sahaja-sādhanā, the spiritual practice, and sahaja-samādhi, the aim of such practice, remain a common thread among various Hindu and Buddhist Sahajiyā practitioners. While the terms sahaja-jñanna and sahaja-samädhi gathered steam in the nineteenth century religious literature of Tagore, Sen, or Bhaktivinoda, all three steer away from the term sahajiy $\bar{a}$ when describing themselves or any of their epistemological terminologies. Sahajiyās in modern Bengal continued a tradition of tantric sexo-yogic practices that, as we shall see in this section, were too sensational for the middle-class, 'genteel' society to include in their worship.

Tantric worldviews and practices have always existed as esoteric undercurrents of Indian religious life, often hiding beneath the surface, like the Phalgu river that flows past Gayā in modern day Bihar, India. In one of the retellings of Rāma's story, the river flows underground because Sita curses it to vanish from human vision. Yet, at this same place, Sita is said to have offered pinda (ritual oblations) to Daśaratha, her father in law, while they were in exile, so the site continues to host a sacred pilgrimage where Hindus gather to offer oblations to their ancestors (Bose and Bose 2013). While the river apparently has strong streams, they are not visible to the pilgrims who make such offerings. This hidden nature is an approximate metaphor for sahajiyāism, which has strong currents that flow underneath the surface of more socially acceptable Hindu norms. There is no doubt that the sahajiya tradition is secretive and extremely difficult to study, creating a hall of mirrors that only a few scholars have thus far been able to expertly explore and represent (Lorea 2018).

Kānhā, one of the earliest Buddhist sahajiyās, said that explaining sahaja is like speaking with a deaf person about a complex idea-the more you speak, the more the listener misunderstands (Shahidullah 1974, p. xxvii). Thus, there has been a long-standing debate among scholars, outsiders to 
the religious tradition, about the exact nature of sahaja-sādhana within the Vaiṣnava community in the post-Chaitanya period; however, the theory that its earliest traces return to Buddhist sahajiyā traditions in Bengal is a subject of substantial scholarly consensus. Haraprasad Sastri's discoveries of Buddhist Bengali lyrics and the subsequent publication of Hājār Bacharera Purāna Bāngāalà Bhāsāye Bauddhagāna o Doha (Shastri 1916) gave birth to a new realm in the study of Indic literature, language, culture, history, and religions. Manindramohan Basu's The Post-Chaitanya Sahajiya Cult (Bose 1930) remains another milestone in the development of this field of study, and Sasibhushan Dasgupta's 1946 magnum opus Obscure Religious Cults (Dasgupta 1962) continues to be a historic landmark in the study of sahajiyāism.

The origins of Vaiṣnava sahajiyās' tantric worldviews and practices could be read back into the foundational text of the Vaișnava tradition, the Bhägavatapurāna, and the subsequent narrative and ritual traditions surrounding those stories of Kṛnna that came after (Bryant 2007, pp. 4-9). As the tradition evolved, new characters began to appear in various Kṛnna narratives. This was the particularly the case for his beloved Rādhā, who was never explicitly named or discussed in the Bhägavatapurāna or its earliest commentaries, such as Śrīdharasvāmīn's Bhāvārthadī ikika. However, by the time poets like Jayadeva (twelfth century) wrote the Gĩtagovinda, Rādhā was a fully developed character, and the previously unnamed lover of Kṛ̣na in the Bhāgavatapurāna entered popular culture as if she had always been there (Dasgupta 1957). As I have explained elsewhere (Ghosh 2013), the narratives of Rādhā and Kṛnna's esoteric love plays $(l \bar{l} \bar{l})^{2}$ not only invited serious exegesis within the devotional schools of Vedānta ${ }^{3}$ but have also given rise to widespread cultural interest among the literary, pictorial, and performative arts of South Asia.

The Bhägavata tells its readers that Krṣna is not an ordinary human lover, but rather the ultimate personified aspect of the divine; he has a love affair with an unnamed heroine, $\bar{a} r \bar{a} d h i t \bar{a}$, which implies Kṛnna's 'best worshipper'. ${ }^{4}$ The text claims that Kṛnna is bhagavān svayam ${ }^{5}$ (i.e., the Supreme Person, manifested in a sweet personal form) that hides his godhead-ness for the sake of tasting loving relationships ( $\mathrm{ras} a$ ) with his beloved devotees. ${ }^{6}$ It further asserts that the other prominent conceptions of divinity found in the Vedas or the Upanisads - that is, the impersonal Brahman (the substratum of everything) and the indwelling paramātman (the supreme self within each being) that jiñanis (seekers of knowledge) or yogins (ascetics) pursue through austerities and penance-are merely external manifestations of Krṣna, the divine person. According to this way of thinking, not only is this personal vision of divinity the sweetest (madhura) compared to Brahman or paramātman, but Kṛṣna's amorous līlās and a personal relationship with him (śrnggāra) are regarded as even more attractive. ${ }^{7}$ Krṣna's apparent moral transgressions are considered sacred and sweet by his devotees-in the text, as in their religious practice-because they take place within the frame of unselfish devotion (suddha bhakti).

2 Lìlā is a spontaneous and joyful act, performed in 'a state of rapt absorption comparable to that of an artist possessed his by creative vision or to that of a child caught up in the delight of a game played for its own sake' (Hein 1995, p. 15; Dimock 1989)

3 Vedānta is one of the classical philosophical schools of Hindu orthodoxy and is related to the more ritualistic Uttara-Mimāmsā. By the 8th-10th centuries, Śamkara, a monist hermeneutic, expounded on the philosophy of oneness, Advaita, that caught the imagination of the Brahminical intelligentsia. It asserted the ultimate ontological one-ness of the individual and the non-personal absolute reality, brahman. In the centuries following Śamkara, several philosophers, including Rāmānuja, Mādhva, Vallabha, and Caitanya, critiqued his soteriology and worldview. They developed an alternative, 'dualistic' reading of Vedanta that gave prominence to the difference between the personal aspect of godhead (iśvara) and the individual metaphysical self (jĩva), as well as the loving relation between them (bhakti) (Flood 1996, pp. 244-50).

4 Vyāsa and Shastri (1983), 10.30.28. The later commentarial tradition identifies her as Rādhā, but the text itself mentions only 'ārādhitā', meaning 'the best of Krishna's worshippers'. For further information see Schweig (2005, pp. 232-33).

5 Vyāsa and Shastri (1983), 1.3.28.

6 Rasa does not have an equivalent word in English and can have a variety of meanings ranging from sap, taste, and flavor to humidity; it is and is different from $r \bar{a} s a$, which is a circle dance. It is also important to note that although Krṣna was well

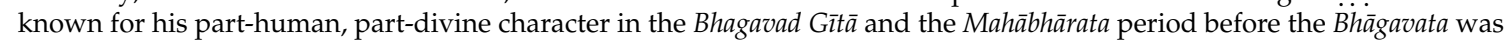
finalized, Krṣna's aspect as a lover became prominent with the composition of the later Puranas. There are references to erotic-sacred love in the works of the ninth-century Tamil mystic Andal, who composed poems glorifying Krșna in which she imagines herself a cowherd girl craving marriage to Krṣna, yet constantly living with the pangs of separation.

7 The 'sweetness' of Kṛsna's līlas are perhaps best described in the famous eight verses of the 'Madhurāṣtaka' by the sixteenth-century mystic Vallabha. See Raghavan (1948, p. 255). 
The recitation of Kṛnna's erotic exploits as described in the literary and ritual traditions following the Bhägavata, and meditation upon them, became a prominent aspect of the theology and praxis of the Vaisnavas ${ }^{8}$ of Bengal and Vraja around the fifteenth and sixteenth centuries due to the efforts of Caitanya (1486-1533), among others. ${ }^{9}$ Caitanya was regarded by his followers as a combined avatara of Rādhā and Kṛ̣na. He practiced public, loud singing of Kṛ̣na's names accompanied by dancing (sankirtana) as well as quiet, intimate recitation of the names (japa) and meditation on the līlās of the Bhāgavata. ${ }^{10}$ These practices, he believed, led ordinary humans, trapped in mortal bodies, to experience love for Kṛ̣na in the mood of the gopis of Vraja, the cowherd maidens who were in love with Krṣna, and in the achievement of this highest goal, experience direct participation in Kṛnna's divine līla. ${ }^{11}$ Caitanya's movement was relatively successful in its expansion in the certain regions of India-especially Bengal, Orissa, and the Braj area. By the nineteenth century, Vaiṣnavism claimed a following of approximately one-fifth to one-third of the Bengali population. ${ }^{12}$ Caitanya's efforts have had a great impact, and the narrative of Rādhā-Kṛnna found in the Bhăgavata has, through generations of devotees, become deeply embedded in the cultural fabric of Bengal.

The theology of Caitanya Vaiṣnavism and Kṛnna's popularity in the religious life of Bengal was, however, met with suspicion and aversion during the colonial period. Bengal was one of the first loci of India's encounter with Europe, and this affected the status of several indigenous traditions. Much of the Bengali urban population absorbed a Victorian puritan ethos not only through colonial and missionary channels but also through a new Western-educated, indigenous elite often called the bhadraloks. ${ }^{13}$ Many Westerners and Western-educated bhadraloks perceived Kṛnna as vulgar and depraved, and this phenomenon turned out to be a watershed moment in the history of Caitanya Vaiṣnavism in Bengal. For the bhadralok, Kṛnna's amorous tale was a source of embarrassment as much as it was fodder for the criticism of the missionaries. Further, the fact that some of the Vaisnavas followed tantric practices and ritually used one of more of the five ' $M$ 's—namely māmsa (meat), madya (alcohol), matsya (fish), mudrā (hand gestures, sometimes depicting phallic symbols and sex acts), and maiththuna (sex)—didn't sit well with urban middle class Bengali sensibilities. Some sahajiyā practices involved the male adherent imagining himself as Kṛnna, and the female participant as Rādhā, and engaging in ritualizing their erotic relation with the aim of sublimating, and eventually transcending sexual passion.

Many agreed with the missionaries and regarded 'Hindooism' as the home of 'deviant practices' such as idol worship and debauchery, of which Vaiṣnavism was considered a primary example. Kṛ̣na's

8 Vaisnavas are usually known as devotees of Viṣnu or one of his incarnations; they constitute one of the most common traditions of Hinduism. In Bengal and Vraja, Kṛ̣na was worshipped sometimes as the source of the incarnation (or avatara) of Viṣnu rather than as an incarnation of Viṣnu, but his devotees are nonetheless known as Vaisnnavas.

9 Caitanya was a proponent of the Bhāgavatapurāna and śrngīāra rasa (i.e., amorous love of god), which he viewed as the highest form of devotion. He is regarded as the combined incarnation of Rādhā and Krishna by the Vaisnavas of Bengal. See (Gosvāmi et al. 1999).

10 Though Rādhā-Kṛ̣na bhakti had already been presented by predecessors such as Jayadeva, Caṇịdāsa, and Vidyāpati through lyrics such as Gita Govinda and Padyāvalis, it was Caitanya who actually popularized Kṛ̣na in the Eastern regions of India. See Chakrabarti (1985, pp. 52-121).

11 Regarding the system of meditation where the aspirant imagines himself to be a lover, friend, or parent of Krishna, see Haberman (1988, pp. 61-86).

12 Chakrabarti (1985, p. 384) quotes the census figures of 1881 and 1901 to corroborate these statements.

13 These bhadraloks emerged as a new Western-educated social class flourishing along with the expansion of the British East India Company's rule of the Indian subcontinent. Broomfield describes the class as 'a socially privileged and consciously superior group, economically dependent upon landed rents and professional and clerical employment, keeping its distance from the masses by its acceptance of high-caste prescriptions and its command of education; sharing a pride in its language, its literature culture, and its history; and maintaining its communal integration through a fairly complex institutional structure that it had proved remarkably able to adapt and augment to extend its social power and political opportunities'; Broomfield (1968, pp. 12-13). On the one hand, bhadraloks responded to European criticism of Indian culture and religion, but on the other hand, they became religious authorities for the colonial administration, which needed interpreters for its understanding of law and custom among the indigenous religions. As a result, the bhadraloks explored Hinduism in an effort to improve their own understanding, as well as that of the colonial administration; in the process, they became pioneers of Hindu revival and reform. 
life story, the religion that had grown around him, and the reenactment of his amorous lila by some of his non-orthodox tantric worshippers were viewed as an example the immorality, promiscuity, blind faith, and idol worship rampant in Hinduism. Moreover, Kṛ̣na's 'cult', as it was called, was regarded as the archetype of the 'primitive state' of Indian civilizations. An 1835 court judgment from another part of India clearly revealed such perceptions: 'It is Krishna the darling of 16,000 Gopees; Krishna the love hero-the husband of 16,000 princesses ... This tinges the whole system (of Hinduism) with the strain of carnal sensualism, of strange, transcendental lewdness' ${ }^{14}{ }^{14}$ For the missionaries, this was a religious occurrence that needed to be eliminated as part of their 'civilizing mission', and for many leading bhadraloks, it was an issue to be handled as part of their own reform of Hinduism.

What characterized the sahajiyā hermeneutic to the stories of Krṣna and the gopīs, or for that matter Caitanya, was its erotic component, which often translated into tantra-based sexo-yogic rituals for adherents. In 'heterodox' sahajiyā traditions, Rādhā and Kṛṣna were not just the ultimate sacred masculine and feminine - they were immanent in the physicality of all things male and female in the phenomenal world. The union of Rādhā and Kṛnna in the Vaiṣnava texts, especially the affair between them, represents not only the most intense emotions that humans can experience-ritualized and sacralized, it could lead to the ultimate form of transcendent freedom from the phenomenal world. Thus, the sahajiyās are said to imagine the human male as the embodiment of Kṛ̣na, and the female as that of Rādhā, and the love between them ritualized in the form of sexo-yogic practices leads to samā $h$ hi (a state of perfect meditative absorption).

For the more so-called orthodox traditions, of which Bhaktivinoda is a good example, a cigar is just a cigar, as in the apocryphal Freudian quote. ${ }^{15}$ In this form of Hindu spirituality, the semantic range of a cigar in Freudian psychoanalysis is similar to that of sahaja and other allied terms, such as such as prema (love), sādhan (spiritual practice), and samādhi. While Kṛṣna's dalliances with the cowherd maidens in Vrnndāvana can be used to construct a theology of transcendence through immanence, traditions characterized by more puritan strains of thought insisted on attaining transcendence beyond immanence. The sahajiyās were known for having an unmarried secret lover with whom they engaged in their sahaja practice, the males deeming themselves Kṛṣna and the females Rādhā. Whether they actually did this, or their (poor) reputation spanned beyond what they were comfortable sharing with any circles beyond initiated members, has been a point of contention. For the non-sahajiyā Vaiṣnavas, any erotic dimension of religion was always metaphysical, or psychological, never phenomenal. Reflecting on this tension, Wendy Doniger puts the question as this: 'Did the Tantrics actually have Tantric sex?' She responds with three guesses:

“FIRST GUESS: They did.

Variant 1: Once they did it; now they talk about it.

Variant 2: First they talked about it, and then they did it.

SECOND GUESS: It was always all in their heads.

THIRD GUESS: They always did it and imagined it at the same time.

The historical argument implies that the Hindus themselves bowdlerized their own tradition: "No one is swallowing anything; we're all just meditating".

Whether they did it, imagined it, or did it while imagining it, sahajiyās would usually speak about it only in code language, a sandhya-bhāșā, that non-initiates would not understand. However, none of this was socially acceptable in the cultural context of urban colonial India, where Victorian prudery was more strictly observed than in Victorian England itself. Needless to say, the missionaries, Orientalists and their ilk engaged in various forms of sahajiya-shaming. Hindu reformers (demonstrating what

14 Although this particular case was fought against the Vallabha-Vaiṣnavas in Bombay, it is representative of the situation in Bengal and other parts of India. See Bombay (Presidency, p. 213).

15 (Elms 2001). 
Doniger calls the 'Hindu reformer's Stockholm syndrome') became convinced by the rhetoric, and they began to shame themselves too (Doniger 2009, p. 597).

Rammohan Roy, often called the 'father of modern India', claimed in Goswamider Sahit Bichar that:

"it can be easily rationally derived that Bhāgavata is not a natural commentary of the Vedānta Sūtra and it is only so till 'let us therefore enquire into Brahman (absolute reality) ... After stealing the clothes of the cowherd maidens (gopīs), Kṛnna asked them to become his servants, to do whatever he wants them to and personally come to him naked, smiling, and he would give their clothes back... Their cheeks rubbing against his (in their circle rāsa dance), and any of them would take a chewed betel leaf from Kṛnna's mouth. Why don't educated people objectively analyze which Śruti or Śntra (philosophical aphorisms) of the Vedānta supports such immoral acts?" (Roy 1818, pp. 51-52)

A century later, Bengali author Bankim Chandra Chatterjee, a contemporary and a colleague of Bhaktivinoda in the British civil service, wrote in Krṣna Caritra: "I have studied the Purānas and the historical materials to the best of my ability, with the purpose of ascertaining the real character of Śrīkṛṣna [sic] as described in the Purānas and history, and I have come to the conclusion that the current sinful anecdotes about Śrīkrșna [sic] are without any foundation and if these were discarded, what we are left with is of the utmost purity, sanctity and grandeur." (Chattapadhaya 1886, p. 1).

The recovery of a sanitized Kṛnna as a national hero became a pet project of Hindu reformers, if they were willing to recover a Krṣna at all. They preferred the kinglike and diplomatic Kṛsna of the Mahābhārata as a role model rather than the erotic and sensuous Kṛnna of the Vaiṣnava poets. The terms sahaja and sahajiya experienced a similar fate. Hindu reformers denounced the idea of the practice of any form of sexuality outside of a conventional heterosexual marriage and tried to recover, reclaim, and resurrect the term sahaja, giving it a completely different metaphysical, nonsexual, Vedāntic spin. The first person to use the word in the sense of 'innate intuition' was Tagore, one of the original founding members founders of the Brahmo Samaj and a successor of Roy.

In essence, colonial Indian responses to sahajyāism were multipronged: there were Protestant missionaries who continued with their vitriol, and there were Orientalists who exoticized, whether they agreed with the missionaries or not. Besides these, there were scholars like Haraprosad Sastri, among others, who looked at it with an almost clinical gaze, and then there were Hindu practitioners, both Vaisnnavas and non-Vaisnnavas, who agreed on the public unacceptability of the scandalous behavior of the sahajiyās.

Lucian Wong notes how the polemics against sahajiyās were not just 'a definitive index of colonial-wrought rupture' and suggests that critiques of sahajiyās were existent in pre-colonial Gaudīya literature, remarking that "[they] are indicative of a movement towards a brahmanically aligned normativity" (Wong 2018). He further argues that non-Vaiṣnava brahmins did not always see eye to eye with Vaisnavas, brahmins or otherwise, due to issues of theology, ritual, or caste. In fact, they created strong alliances when it came to polemics against sahajiyās before and during the colonial period. The main issue was not just the hermeneutics of sahajiyaism that propounded the necessity of sexo-yogic practices, but during the colonial period, also the question of moral impropriety that struck at the Victorian puritan heteronormativity embedded in Bengali bhadralok culture.

What brought Vaiṣnavas as a group under scrutiny was the fact that sahajiyās would call themselves Vaiṣnava, just as orthodox practitioners did. For bhadralok Vaiṣnavas, who lived according to 'socially respectable' standards of sexuality, the shame of being associated with sahajiyās-who were said to ritually copulate with out-of-wedlock partners, especially others' spouses, while claiming allegiance to the same forms of divinity-took the shape of polemics, and sometimes, rancor. It is no surprise that the printed periodicals and books of the Vaisnavas of the colonial era, most of which were published in urban centers by bhadraloks (and not sahajiyās), present a clear reassertion of sexual norms based on textual sources from the time of Caitanya himself. The next two sections discuss this 'reclaiming' or 'arrogating' of terminology, also examining the conceptual scope of the term sahaja 
without its sexual connotations as it takes on a purely metaphysical and cognitive bent in Brahmo and Vaiṣnava epistemologies.

\section{Sahaja-jñāna, Ātma-pratyaya, and Pratibhā}

In his book India and Europe, Wilhelm Halbfass notes that experience is one of the most ambiguous and evasive terms in the recent literature on comparative religion, philosophy, and theology, a fact that "is most conspicuous in the works of Indian religion and philosophy" (Halbfass 1988, p. 378). He critically analyzes S. Radhakrishnan's use of the word and how it snowballed into a major concept in several important Western intellectuals' understandings of Indian philosophy in the twentieth century; he names, among others, H.G. Gadamer, 'the elder statesman of European philosophy'. Halbfass's main argument in his discussion of experience and, in that context, intuition, is that the modern Hindu invocation of experience as the common ground of all religions constitutes "a means of Hindu self-affirmation. It may be true that all religions have their roots in experience, but it is Hinduism which is the religion of experience par excellence" (Halbfass 1988, p. 382). In support of his view, he liberally quotes S. Radhakrishnan, and to a lesser extent Aurobindo Ghosh, and especially bases his reflections on Radhakrishnan's The Hindu View of Life (Radhakrishnan 1962) and The Brahma Sütras (Radhakrishnan 1960). In his discussion of experience, he also briefly mentions the contributions of Tagore and Sen in their formulation of ātma-pratyaya and sahaja-jñāna as two of the characteristics of the modern Hindu experimentation with 'experience' and 'intuition'.

Halbfass argues that the introduction of the ideas of 'experience' and 'intuition' in modern Hinduism is merely an exercise in 'self-affirmation'. He echoes Paul Hacker in saying that "the Hindu tradition is reinterpreted and transformed by applying Western concepts and responding to Western expectations and presupposition" (Halbfass 1988, p. 380). However, this analysis is debatable. For the most part, Halbfass's argument is no doubt quite valid and strong, but apart from the moot point of according colonizing powers more agency than they deserve, it would be more apt to state that Hindu philosophers were often situationally coerced to respond to 'Western expectations and presuppositions' and applied indigenous concepts—such as anubhüti (experience), ātma-pratyaya, or sahaja-jñāna-suitable for the situation.

Further, I would like to argue for a more nuanced reading of the differences between 'experience' and 'intuition', which Halbfass clearly seems to conflate (pp. 379-85) and suggest that these are distinct concepts; speaking of them as if they are the same does not do justice to either. 'Experience', in Halbfass's usage, is not experience that an individual acquires in this phenomenal world. Rather, it is an inner experience 'in the field of religious emotions' (p. 379). This would fall into the category of mystical experiences in which the practitioner comes across something extrasensory that leads to certain presuppositions about the nature of reality. In this usage, the semantic field of 'experience' and the idea of anubhūti merge together. Even a text such as the Tattvaviveka uses the concept of anubhūti appearing in its subtitle-Saccidānanda-anubhüti-but it implies more of a state of realization than an experience.

The key difference between experience and intuition, particularly used in the context of sahaja-jñanna, is that experience occurs as a result of external stimuli, whereas intuition is innate and requires no external agency. Intuitive cognition would thus be a supra-sensory mode of knowing something, a form of tacit knowledge one possesses after having exhausted the possibilities of direct perception (pratyakșa), analysis (anumāna), and so on. ${ }^{16}$ Moreover, intuition is also saha-ja-that is, innate and self-born in an individual being - and thus an individual knows certain things. This idea is perhaps best illuminated by Ralph Waldo Emerson's 1832 poem Self-Reliance:

The little needle always knows the North,

16 For more contemporary discussions on tacit knowledge, see Polanyi and Nye (2015) or Eraut (2000). 
The little bird remembereth his note,

And this wise Seer within me never errs.

(Emerson 1918, p. 394)

Emerson's metaphors of the magnetic 'needle' and the 'little bird' (intuitive cognition) describe the ways in which every human becomes aware of certain self-evident truths. Experience, on the other hand, manifests at a certain point in time and involves external factors, despite the instrumental role of cognition in that experience. Though there is no precedence for sahaja-jñāna or sahaja-samādhi as major concepts in classical Indian philosophy, intuition as a form of epistemology has its own niche and is known as pratibha $\bar{a}$, literally 'a flash of light', or sometimes prajñ $\bar{a}$, or 'wisdom', though it is never really acknowledged as a major method of knowledge acquisition in its own right.

One of the important Sanskrit terms for epistemology is pramāna, or a method of knowing something; what is known (prama) is either valid or invalid based on true or false cognition. For most schools of Indian philosophy, some methods of knowledge are recognized-including pratyakșa (sensory perception), anumāna (logical inference), śabda (testimony), upamāna (comparison) - whether they are accepted as the ultimate source of valid knowledge or not. Then there are other epistemological modes, such as arthapatti (postulation or circumstantial implication), anupalabdhi (non-cognition), sambhava (inclusion), aitihya (tradition or precedence), and a $r$ śa the (authority of a sage). ${ }^{17}$ While sensory perception, logical inference, and testimony claim the most space in the Indian philosophical discursive practices on epistemology, the others also appear in various contexts, and are sometimes subsumed under pratyakșa, anumāna, and śabda. For instance, the Vedānta school focuses on testimony as the highest method of knowledge, supported by logical inference or comparison, while the philosopher Cārvāka assumes only sensory perception to be valid. The Vaiśeșika proponent Kanāada, on the other hand, limits his epistemology to sense perception, inference, and testimony (which is subsumed under inference). Beyond the first three, there are methods of knowledge, such as postulation or circumstantial implication, that are common in Mīmāṃsā and to an extent Vedānta, but dismissed by almost all other schools of philosophy.

A detailed discussion of epistemology in Indian philosophy would be secondary to the main arguments of this project, so let it suffice to say that pratibhā does not really figure in the primary or even secondary methods of knowledge in six orthodox schools of Indian philosophy. Though we do find references to pratibhā (or parallel concepts) in various philosophical texts, they are incidental to a discussion of the main methods of knowledge-except in Yogasütras, where it is one of the key epistemological forms, and in Buddhist literature, where we find abundant discussions of the parallel idea of praj $\bar{n} \bar{a}$ (Kaviraj 1984, pp. 1-44). Gopinath Kaviraj explains that pratibhā is found in Indian philosophical literature:

“... in the sense of wisdom characterized by immediacy and freshness. It might be called the supra-sensuous and supra-rational apperception, grasping truth directly, and would therefore seem to have the same value, both as a faculty and as an act in Indian philosophy ... [pratibhā indicates] any kind of knowledge which is not sense-born nor of the nature or an inference ... Such knowledge is considered transcendental, being held to be free from the time and space limitations, which are imposed as a matter of necessity on all inferior knowledge and from the indispensable conditions which govern the origin or manifestation of the latter. Consequently, we find in every respect a strongly marked contrast between the two. This higher knowledge dispenses, in its rise, with the need of sense organs and unlike reflective judgment, with that of rational faculty. It reveals the past and the future

17 This list of 10 pramānas follows the postulation of seventeenth-century Vaiṣnava theologian Baladeva Vidyābhuṣana's Vedāntasyamantaka. See (Vidyābhușaṇa 1942, p. 1). 
as in a single flash, and also the absent and the remote. Nothing escapes its searching light. (Kaviraj 1923, pp. 1-2)

The semantic scope of pratibhā has sectarian underpinnings beyond what is mentioned above. Kaviraj further notes that this term also appears in Âgamic literature, 'especially in the Tripurā and Trika sections of it, the power of self-revelation or self-illumination of the Supreme Spirit, with which it is essentially and eternally identical' (p. 2). However, in terms of usage, the former meaning has greater relevance to epistemology than the latter, sectarian one.

The word pratibha is mentioned and receives substantive treatment in yoga philosophy. Yogasūtras 3.33-36 describes this as the 'source of knowledge of everything' and thus deserves our attention. This form of 'pure cognition' in yoga philosophy is the closest parallel Bhaktivinoda's definitions of sahaja-jñāna and sahaja-samādhi, and we shall return to this discussion in ensuing sections. In sum, however, we can say that through a focus (samyama) on the last three limbs of yoga, "the knowledge of the mind ensues ... and from this, pratibhā as well as hearing, touch, vision, taste, and smell are born". ${ }^{18}$ According to the commentator Vijñānabhikṣu, this kind of intuitive cognition is not only attained independent of a teacher-for the Yogasütras' main commentator, Vyāsa, this intuition precedes omniscience in a yogi, just as the light of the breaking dawn appears in the horizon before the sun becomes visible. The Yogasutras 1.42-3 further acknowledges the differences between a word that is signifier, the object that is signified, and meaning (i.e., significance), as well as how a spontaneous perception of non-difference between them (vikalpa) aids ordinary thinking in the realm of worldly convention or sanketas (Patañjali and Āranya 1963, pp. 92-97). However, in a higher meditative state, when the ultimate aim of yoga (i.e., samādhi, or pure concentration) is achieved, the differences when verbal references to objects-and, thus, the conceptual element based on language - are fully removed, and a pure intuitive form of cognition ensues.

Outside the confines of the so-called six orthodox schools of Indian philosophy, one can find references to pratibhā in Jain and Buddhist literature, with the Buddhist philosophical concept of prajñā overlapping with yoga philosophy particularly well. Beyond the realm of Indian philosophy and Hindu, Jain, and Buddhist soteriology, intuitive cognition appears in theories on grammar, poetics, and aesthetics in works such as Bhartṛhari's Vākyapadīya (fifth century), Ānandavardhana's Dhvanyāloka (ninth century), and the many masterpieces of Abhinavagupta (late tenth century to eleventh century). The role of intuition in this domain is much more pronounced than in the epistemologies of Indian philosophy, as well as its creative role in cognition of language, conceptualizing poetry, or having an aesthetic experience. In fact, Abhinavagupta is said to have combined several usages of the term to suggest that the "concept of intuition underlies the unity of the imaginative enterprise that is an aesthetic continuum comprising the whole of the theater-the poet, actor, and audience. This unity in turn gives the theater its peculiar aesthetic modality and coherence, beginning with a desire to enjoy oneself and ending in the relishing of a rasa, an aesthetic mood" (Kuanpoonpol 1991).

When it comes to Indian philosophy, linguistics, poetics, or aesthetics, the word pratibha and the concepts associated with it come closest to the idea of sahaja-jñāna, although with distinct differences. The notable characteristic of sahaja-jñanna is its precise formulation of axiomatic statements that for both Tagore and Bhaktivinoda serve as the basis of their Brahmo and Vaiṣnava epistemic systems. In this sense, sahaja-jñāna has a stronger parallel to a Cartesian formulation such as 'Cogito, ergo sum', where a certain axiomatic truth is derived that is co-born and spontaneously realized, although sahaja-jñāna is more intuitively apprehended than the rational thought process that is inherent to Descartes's formulation.

The very term sahaja-jñanna, however, is conspicuously absent from the Sanskritic literature of the Vaisnavas in Bengal, Braj, and Orissa, the regions to which Caitanya's movement spread. Even the word pratibhā does not occur, and in key texts of epistemology such as Baladeva Vidyābhuṣana's

18 pratibhād vā sarvam (33) and tatah pratibhā-śrāvana-vedanādarśāsvādavāartāhjāyante (36) (Patañjali and Āranya 1963, pp. 308-12). 
Vedāntasyamantaka, intuition does not even merit a discussion, though almost 10 other epistemic modes are discussed. In the Vaiṣnava tradition, thinkers from Jiva Goswamin (sixteenth century) to Bhaktivinoda described the role of śabda or śruti as paramount. The theologies of the Vaiṣnava traditions had developed within the discourse of Vedāntic commentaries, and thus Rāmānuja, Mādhva and others composed their commentaries in refutation of Śamkara's. One of the peculiarities of the tradition that emerged after Caitanya was the claim that the Bhägavatapurāna is a 'natural commentary to the Vedānta Sūtra'. Yet Baladeva Vidyābhuṣana needed to compose another commentary called Govindabhāsya in order to defend this tradition, while also acknowledging that the Gaudieyas were a part of Mādhva's tradition, which already had a commentary on the Vedāntasūtras. As some recent scholarship has demonstrated, such a complication in commentary writing was influenced at the time more by political than intellectual needs (Okita 2014).

In terms of the epistemology of the Caitanya Vaisnava tradition, the third aphorism of the Vedāntasutras (1.1.3) comments on the stance of the school by claiming śāstrayonitvāt ('the proof or source of [knowledge of Brahman]') is in sāstra ('sacred texts'). The word yoni literally means 'womb' and is used as a metaphor to describe śāstra in Śamkara's commentary, which is one of the earliest exegeses on the question of epistemology. It states that

"Brahman has no form etc. and so cannot be cognized by direct perception. Again, in the absence of inseparable characteristics, as smoke is to fire, it cannot be established by inference or analogy (upamāna). Therefore, it can be known only through the scriptures. The scriptures themselves say, 'One who is ignorant of the scriptures cannot know that Brahman' ... no doubt, as already referred to in the previous sutra, these means of right knowledge also have a scope, but it is only after Brahman is established by the Scriptures-as supplementary to them and not independent of them." (Bādarāyaṇa and Vireswarananda 1936, p. 29)

What is evident from this passage and commentary to the Vedantasutra are the valid means of knowing Brahman that are acknowledged. This issue also finds substantial discussion in the key texts of other schools of Indian philosophy, such as the Yogasūtras or the Nyāyasütras. In each of these texts, inference and analogy are discussed in detail, but nowhere does the idea of intuition claim space. Furthermore, in the Vedāntasūtras, the idea that sacred texts, such as the Vedas or Upanisads, are really the only way of understanding the nature of reality or Brahman is a key presupposition. Samkara clearly lays out the idea that the other epistemological means of knowing Brahman are valid only insofar as they support what is known for the ultimate form of epistemology: knowledge received from sāstras. Though the later commentators of the Vedāntasūtras disagree with Śamkara's foundational points, they all seem to concur on the indispensability of this particular epistemological mode.

In his commentary Govindabhāsya, Baladeva Vidyābhuṣaṇa also reaffirms this principle as he defines the visaya (subject matter) of the sūtra by mentioning an opposing point of view (pürva-pakșa). He asks whether Brahman can be known by means other than the Upanișads, stating, 'The Philosopher Gautama and the others of his school hold that Brahman can be known by inference and they take their stand on the word "mantavya" (to be reasoned out), as is used in the śruti passage, ātmavāre mantavya from Bṛhadaranyaka Upanișad IV.5 and since Brahman is the object of thought, it can be comprehended through dialectical reasoning'. Vidyābhuṣaṇa (1912) vehemently denies this non-Vedāntic stance and uses the circular reasoning characteristic of religious hermeneutics to argue that sūtra 1.1.3, mentioned above, is the proof that Brahman cannot be known through any other means. Though one translator, Śrīsa Candra Vāsu, uses the word 'intuition' in his rendition of this passage ('[Brahman], being inconceivable, is understood by the Vedānta revelation; and not by argumentation, but by intuition') the original text suggests no term that could possibly translate to intuition. ${ }^{19}$

19 atha jagaj-janmādi-hetuh puruṣottamo'vicintyatvād vedāntenaiva bodhyo na tu tarkair iti vaktum àrambhah. 


\section{Tagore, Roy, and Sahaja-jūāna}

A general articulation of sahaja-jñāna that was bereft of its actual sahajiyā underpinnings or its Vedāntic resonances was first found in the works of Tagore; it appeared sporadically as he articulated his ever-evolving Brahmo theology throughout his lifetime. The idea of aham-pratyaya, in which an individual being, either through instructions from a teacher or through meditation, realizes one's ātman and its relationship with Brahman, is common in the Upanishadic canon. Tagore first used the term atma-pratyaya, self-cognition, in this sense-the realization that there is a distinction between the objects of the external world and a self that observes this through the medium of the mind, senses, intelligence, and so on. Though his predecessor Roy did not develop the ideas of ātma-pratyaya or sahaja-jñāna in any of his works, and neither did he talk about the idea of intuition as a valid epistemological method, for Tagore, the origins of both traced back to Roy. In a lecture titled 'Brāmasamājera Pañcavimsati Parikșita Vrttānta,' delivered in 1863 on the twenty-fifth anniversary of the founding of Brahmo Samaj, Tagore emphasized that sahaja-jñāna derived from Roy himself. Invoking the name of Roy, Tagore claimed:

Another great aim of Roy was to avoid conflict and acrimony for the sake of dharma, but everyone should worship the one God (îśvara). He didn't believe that the general mass of people would ascertain the supreme being through sahaja-jñāna or ātma-pratyaya. Though he knew well that to preach and protect a religion there was necessity for a revealed scripture, but the ground of his faith was sahaja-jñanna. If that was not true, how was he able to grasp the essential truth from all the religions? Though he couldn't confidently ask people to have faith in ātma-pratyaya, he himself was guided by ātma-pratyaya. He saw the Vedas, Qur'an, Bible, Purānas, Tantras, Mantras, and everything else through the light of sahaja-jñāna, and depending on àtma-pratyaya, he expressed the method of worshipping the one God. (Tagore 2017)

But how much veracity does Tagore's reading of Roy have? Did Roy really depend on sahaja-jñanna in his apparent religious eclecticism when he formulated the theology, liturgy, and practice of Brahmoism?

In that very same lecture, Tagore also notes that Roy's religious aims were tripartite and consisted of efforts against idolatry, the synthesis of a universalistic Vedānta, and promotion of interreligious harmony (pp. 10-12). In pursuit of these three aims, it is quite evident from the works of Roy himself that his Vedāntic Brahmo theology and the recognition of an attribute-less Brahman as the 'one true God' was the lowest common denominator of a theos that came from his studies of Islam, Christianity, and Hinduism. At the age of sixteen, Roy began his studies of Arabic and Persian and read the Qur'an to the best of his ability. He became convinced that any God had to be formless, and, for him, the various gods of Hinduism did not quite make the mark. Later, during his study of Christianity, he was employed by the Baptist missionaries, better known as the 'Serampore trio', but one of the Baptist missionaries himself was converted through his dialogues and conversations with Roy to Unitarian Universalism. In all of this, Roy was firmly grounded in textual exegesis, a common practice among both evangelical Christians and Brāmanical Hindus. He never mentions the idea of intuition, sahaja-jñāna, or ātma-pratyaya, or even introduces an epistemic method that resembles anything close to what Tagore claimed about him.

Roy's conclusions about Christianity were very similar to those he drew about Hinduism, and for him, a substantial amount of idolatry crept into both Christianity and Hinduism; the worship of Jesus was a form of idolatry too. In this, Roy's critique of Christianity was akin to the Islamic notion that Jesus was a rasúl, or a prophet of God, rather than God himself. Christians were mistakenly worshipping the messenger, and just as a reform within Christianity led to an apparently 'theologically pure' version of the religion in Unitarianism, Hinduism needed something similar. Though Roy had never heard of Thomas Jefferson, he did what Jefferson had done to the Bible-Roy culled out all the sections that spoke of miracles or anything supernatural, retained those sections of the New Testament that presented the ethical Jesus, and published The Precepts of Jesus: The Guide to Peace and Happiness 
(Roy 1820). For Roy, as much as it was for Jefferson, it was the humanness of Jesus that was 'logical', and the various aspects of divinity that Jesus' followers ascribed to him was 'mythical'. The only difference between Roy and Jefferson was Roy's Vedāntic perennialism, which was not too far from the Jefferson's deism. Neither said much about the wrathful judging God of the Hebrew Bible, and they both focused most of their attention on the New Testament.

Roy's theology was, in this sense, more Protestant than intuitive. His idea was to cut through the bureaucracy of religious authority and get straight to the primary texts of Hinduism: the Vedas, or 'the Veds', as he called them. Even in this, he ignored the actual Vedic hymns and focused mostly on the Upanisads, the philosophical appendage to the Vedas. The primary focus of Roy's literary works was not to articulate a systematic theology for the fledging Brahmo Sabha, but rather to excavate some aspects of Hindu theology (he did not call it Hindu) to be able to bolster his stand against what he perceived to be areas requiring social reform. Thus, he took up the elimination of sati-dāha, or the burning of widows, after witnessing his own sister-in-law, Alak Manjari, getting burnt on the funeral pyre along with his elder brother. Later, when he pushed for reform, his arguments were both scriptural and legalistic. Though Roy perhaps did not care about the micro-injunctions of the various Hindu dharma-śassatras, he referred to them nonetheless because the dominant social discourse arose from them. Similarly, Roy's primary focus on the formlessness of divinity stemmed from his campaign against idolatry, which likely originated from his understanding of Islamic, and to an extent Christian, iconoclasm.

In this sense, though Tagore ascribes the origins of sahaja-jñanna to Roy, there is little evidence to substantiate this claim, and it would be indisputable to a historian of ideas that the concept came from Tagore himself. Beginning with the earliest phase of Roy's career-even as early as his Tuhfat al-muwahhidin ('Gift to Monotheists')—and extending to later works, his foundational premises are based on the validity of sacred texts, whether it was the Qur'an or the Upanișads. In this, I concur with the early twentieth-century author and philosopher Sitanath Tattvabhushan's point that "in the prefaces to his edition of the Upanishads and his controversies with the advocates of idolatry and popular Christianity, he nowhere questions the authority of these ancient writings or sets up Reason or Intuition as an independent authority competent to sit in judgment on the accepted scriptures of the nation. Next to the authority of the Upanishads is, to the Raja, the authority of Śankara, their commentator. It is in light of Śankara's commentary that the Rája interprets the Upanishads and the Vedantic aphorisms" (Tattvabhushan 1909, p. 5). Tattvabhushan also states that "It does not appear from his writings that he desired anything more than the removal of the evil customs that had grown in later ages and a return of Hindu society to the somewhat purer state that existed in the later Vedic period. That he contemplated any radical reconstruction of society, seems improbable from his teachings and from the solicitude which he showed, up to the close of his life, not to be excommunicated from the pale of Hindu orthodoxy" (Tattvabhushan 1909, p. 7).

It is apparent that Tagore ascribes to Roy a key epistemological concept of Brahmoism that Tagore himself had a greater role in developing than anyone else before him. It was in his nature not to lay claim to his own accomplishments or give credit to someone else. This was likely out of a sense of humility stemming from his spiritual realizations rather than any political reasons. For instance, after he compiled a key text, Brähmadharma — which became like a de facto 'Bible of the Brahmos'-he insisted his name be left off the cover. He dictated the book to the editor of his journal and compiled it in three hours as an 'inspired text', anthologizing an eclectic range of Upanișadic statements yet choosing to keep it 'authorless' in the spirit of Vedic and Upanișadic texts (Chakrabarti 1916, pp. 163-64).

In order to understand the intellectual history of intuition as an important aspect of modern Hindu and particularly Brahmic epistemology, Tagore's autobiography, or Ātmajīban $\bar{\imath}$, sheds more light on the evolution of this term and the inception of its new meanings than any other text. Further, this autobiography presents a clear tension between the role of Vedic and Upanisadic texts and the invention of intuition as a mode of understanding truth. But what does Tagore's version of intuition look like? And what role does his subjectivity play in it? The answers to this are perhaps best 
approached through an analysis of the biography itself. At the beginning, he reports one of the first intuitive experiences of an apparent spiritual awakening when he finds himself at Kolkata's Nimtala cremation grounds, where he came to witness his grandmother's death and perform the last rites for her. He was 18, he says, when he had this mystical experience:

"My mind could scarcely contain the unworldly joy, so simple and natural (sahaja), which I experienced at the cremation grounds. Language is so powerless, so how can I ever explain anyone the nature of that joy? It was spontaneously natural joy, and no one is able to experience it through argument or logic. The divine itself tries to find an opportunity to outpour such joy ... I returned home [from the cremation] with this joy and dispassion. I couldn't sleep at night, and the main reason behind it was this bliss. It was as if moonbeams of joy kept awakening in my heart ... Later, I attempted to feel the same bliss that I experienced the night before my grandmother's passing. But I could not feel it anymore." (Thākura 1960, pp. 5-7)

Tagore's mystical experience and his yearning to re-experience it is parallel to Eliade's experience where he was 'transfixed with emotions' upon entering his 'fairytale palace' in his own family's living room (Eliade 1990, p. 6). Eliade's experience of being surrounded by light emanating through the heavy green velvety curtains of his living room gave him the feeling that he had 'discovered a mystery'. Throughout his life he kept evoking this memory of the immediacy and authenticity of this mystical experience of witnessing 'light from another world' and attempting to return to it. In a sense, Eliade had a spontaneous, authentic cognition of something that Tagore would have perhaps acknowledged as an intuitive one. Tagore speaks very similarly about his mystical experience, and the arc of his life, as he presents it in his autobiography, speaks to everything he experimented with in the rest of his religious career, including his realization of sahaja-jñāna, much like Eliade's experiences shaped his scholarship. After all, Eliade, like Tagore, ended up attempting to 'recapture this epiphanic moment', and Eliade claims he would "slip into it as into a fragment of time devoid of duration-without beginning and without end" (p. 7).

Though a mystical experience was a catalyst to Tagore's spiritual pursuit, the project of uncovering the meaning of Vedānta and the worship of Brahman remained a key feature of his own spiritual life, as well the institutional dimension of Tagore's religious career. The Tattvabodhini Sabhā that he had founded expanded and eventually merged with the Brahmo Sabha, which was meant to diffuse 'the deep truth of all our shastras and the knowledge of Brahma as inculcated in the Vedanta' (p. 62). For many years, the growth of the Brahmo Samaj was based on the centrality of the Vedāntic philosophy as found in the Upanișads, for which Tagore claimed to have 'profound reverence' (p. 69). However, as Tagore evolved in his thinking, and the Brahmo Samaj expanded and matured, he realized that many of the initial ideas that he had held as core aspects of Brāhmoism had to change. For instance, he thought that the Brahmos could worship Brahman using the Gāyatri mantra from the Rg Veda, but then he realized that the "use of the mantra became too difficult for the majority of the people... and unless one has a firm resolve of ' I'll practice the mantra, or give up my body' one cannot attain success in the mantra" (Thākura 1960, p. 48).

Just as his understanding of the inefficacy of the Gāyatri mantra was based on the realization that the general populace was not able to adopt it as a serious spiritual practice, his stance on the Upanișads, by contrast, was driven by the fact that Hindus revered the Upanișads as the source of the Vedānta. Basing his Brahmoism on such sources would be useful in spreading Brahmoism across India. It could be the unifying religion, rejuvenating the entire nation and eventually helping to achieve independence from foreign rulers (p. 66). However, as the Brahmo Samaj started developing and expanding, Tagore underwent a paradigm shift in his epistemology and the centrality of sacred texts, and the unflinching faith in the Upanișads that characterized most of his intellectual and religious life began to waver.

The story behind this paradigm shift included Presbyterian missionary Alexander Duff, who had published a book called India and Indian Missions in which he described Hinduism as a "stupendous system of error" that Christian missions "must wrench it up by the very foundations" (Duff 1839, 
pp. 519-20,588). Duff continued his evangelical vitriol in the pages of Calcutta Christian Observer and Calcutta Review, calling the Brahmo acceptance of the sacrality of Vedānta a "revealed source" of a "dangerous form of self-delusion" (Kopf 1979, p. 164). Though Tagore defended Hinduism and saw Brahmoism as its progressive reformist dimension, the questions Duff raised fomented an existential crisis within the fledging Brahmo movement centered around issues of epistemology, especially the infallibility of the Vedas. Whether or not the general population of Hindus ever read (or heard) the Vedas, this corpus of texts has commanded reverence since ancient times and was a key identity marker in the making of Hinduism. Roy himself gave utmost reverence to 'The Veds', though he considered 'The Vedant' the 'resolution of all the Veds' (Roy 1885, p. 1). In this same spirit of thinking, between 1844 and 1845, Tagore had sent a few of his students to learn the Vedas in Varanasi, and in 1847 he went there himself to be able to pursue his interest in 'Vedic culture' and 'supreme knowledge'. He confesses his surprise and dismay, after his studies, however, and said that

"I had started with the idea that there were 11 Upanishads in all, and their commentaries had been written by Shankaracharya ... On investigation I found that there were several Upanishads ... Eventually anyone and everybody began to publish anything and everything with the name of Upanishad. In the days of Akbar an Upanishad was again composed with the object of converting Hindus into Musulmans-and It was called Allopanishad. How strange!

Formerly I did not know of the existence of this thorny tangle of Upanishads: only 11 Upanishads were known to me, with the help of which I started the propagation of Brāhma Dharma, making them the foundation. But now I saw that even this foundation was shaky and built upon sand; even here I did not touch firm ground ... Where was the foundation to be laid? I came to see that the pure heart filled with the light of intuitive knowledge-this was its basis. Brahma reigned in the pure heart alone. The pure, unsophisticated heart was the seat of Brāhmaism. We could accept those texts of the Upanishads which accorded with the heart. Those sayings which disagreed with the heart we could not accept."

(Tagore 1916, p. 159)

The idea that the 'pure and unsophisticated' heart was the seat of Brahmoism is quite a departure from the epistemology of Roy and some of the original thinkers and leaders of the Brahmo Samaj. Even the assumption that there were ' 11 Upanishads in all' is demonstrative of a general lack of understanding of how the wider Hindu corpus of texts, which Tagore implicitly acknowledges, actually work. However, it is noteworthy that even in the rejection of the Upanisads as the sole foundation of Brahmoism, Tagore nevertheless retained the validity of those that 'accorded with the heart'. This is where he attempts to define the major characteristics of ātma-pratyaya based on Mundaka Upanișhad, though in 1847-1848 he didn't quite use the term sahaja-jñanna as a synonym yet. But how does one know what 'accorded with the heart' and which segments of the Upanișads 'disagreed with the heart', so to say?

Historically, these questions seem to have been answered through theological dialogues Tagore had with his Brahmo comrades, such as the rationalist editor of his Tattvabodhini journal, Akshay Kumar Datta (1820-1886), his close friend Rajnarayan Basu (1826-1899), and orthodox brahmins such as Ramchandra Vidyabagish (1786-1845). There were other important interlocutors who engaged in public debates with Brahmos, and chief among them was Duff. In April 1848, Tagore's 'discovery' of innate intuition was made public in the pages of the Tattvabodhini in a piece claiming that 'the mental chains that existed for hundreds and thousands of years have now fallen off' — referring to the move away from an uncritical reverence toward the Upanișads (Thākura 1960, p. 378). During its general meeting the next month, the Tattvabodhini Sabhā passed the resolution that they would no longer call themselves 'vedāntapratipādya satya dharma' ('the true religion substantiated by Vedānta'), changing to 'brahmodharma' ('religion of Brahman'). As Tagore's stance on Brahmo epistemology kept 
shifting, and as ātma-pratyaya and sahaja-jñana began to evolve, some of the constructive systematic theologizing on the theory of innate intuition occurred in personal letters.

In one such exchange between Tagore and Basu in 1855, we find an effort to form a systematic theology. Tagore says that ātma-pratyaya is of two kinds: 'svatah-siddha ātma-pratyaya [self-evident self-cognition]' and 'vijñānamūlaka ātma-pratyaya [rationally rooted self-cognition]' (Chakrabarti 1916, p. 502). He further says that "the person who does not debate whether self-cognition is a valid form of pratyaya [cognition/belief], and depends on self-cognition, naturally takes recourse to self-evident self-cognition. One who, through the process of discernment, comes to the conclusion that self-evident self-cognition can never be flawed, becomes dependent on rationally rooted self-cognition ... If natural self-cognition wasn't pre-existing, then a rational explication would not have even been a possibility ... The fact that 'I exist' — who can cast doubt on this self-cognition?" (p. 502). ${ }^{20}$

In his articulation of these two kinds of innate intuition, Tagore shows a disregard for intense textual exegesis that is characteristic of Brāhminical hermeneutics. What he says in the letter implies that truths that one encounters through the rational process are legitimate but need not necessarily be attained exclusively through a rational process. However, self-evident self-cognition seems to be, for him, leading to the same truth conclusions. He did not further explicate the distinctions between the two forms. Within the overall structure of the development of innate intuition, this articulation appears to be a nebulous form of constructive theologizing.

Furthermore, Tagore's formulation of sahaja-jñāna in his autobiography is somewhat reminiscent of Bhartrhari, though there are no references to this ancient Sanskrit thinker, nor is there any evidence that Tagore actually delved into the ideas of pratibhā present in Indian philosophy. For Tagore, the idea came like 'a flash of lightning through this darkness of despondency' and he "saw that the knowledge of the material world is born of the senses and the objects of sight, sound, smell, touch, and taste. But together with this knowledge, I am also enabled to know that I am the knower ... I saw that the child, as soon as born, drinks at its mother's breast. Who taught it to do this? He alone Who gave it light" (Tagore 1916, pp. 49-50). For Tagore, the Upanișadic idea of ātma-pratyaya was, in essence, sahaja, and he used the terms interchangeably for the first time, perhaps around the same year, $1847 .^{21}$ Commenting on an unnamed passage from Muṇdaka Upanișad, Tagore explained sahaja-jñāna in three points:

1. I am, and there is my creator, maintainer, and protector-this is ātma-pratyaya.

2. The one who is my creator, maintainer, and protector is also my well-wisher, friend, shelter, and master. This is self-refential (svata-siddha) ātma-pratyaya.

3. The one who is my well-wisher, friend, shelter and master is the same for everyone else. $\mathrm{S} / \mathrm{he}$ is peaceful, auspicious, and the one incomparable. This is the sahaja-siddhanta, or intuitive conclusion of ātma-pratyaya (Chakrabarti 1916, p. 574).

As Brian Hatcher notes in Bourgeoisie Hinduism (Hatcher 2008, pp. 61-62), Tagore did not fully develop this idea of sahaja, and my own research documents a post-Tagore biography of this idea in the hands of Sen and Bhaktivinoda.

\section{Sahaja-jñāna in Keshub Sen}

Scholars of the Brahmo Samaj, whether affiliated with the movement or not, have indicated the causes of its split were not only generational but also ideological (Damen 1983; Kopf 1979; Sastri 1974).

20 ātma-pratyayake pratyaya karā bhrama ki nā e vișaye siddhānta nā kariyā ye vyekti àtma-pratyayera prati nirbhara kare, se svatahsiddha ātmapratyayera upara nirbhara kare, ar jāhāra vicāra kariyā siddhanta haya je, svatahsiddha ătma-pratyaya kadāpi bhramamūlaka nahe, sei vijñānamūlaka ātmapratyayera upara nirbhara kare. Dui-i àtma-pratyaya ... yadi svābhāovika ātma-pratyaya nā thakito, tobe vijñāna dvārā tāhāra pramāna kadāpi haito nā ... āmi je ekjon àchi, e àtmapratyera upara ke saṃśaya ānite pare?

21 At a very simple level, ätma means self; pratyaya is faith, proof, or notion. See (Halbfass 1988, pp. 223, 396; Hatcher 2008, pp. 13-14). 
The story of the fractures and factions of the Brahmo Samaj has been sufficiently told and retold, and its revisitation is unnecessary here. Despite the split, Sen continued to be a leader in the Brahmo Samaj of India while maintaining distance from Tagore. Later in his career, Sen formed the 'New Dispensation', or 'Nababidhan', in response to factions in his own group that challenged his religious authority. Despite all these institutional developments, he continued to be respectful towards Tagore, who outlived him. Regardless of the history of secession, Tagore continued to be considered the patriarch of the various segments of Brahmo movement, and his idea of sahaja-jñāna continued to be one of the cornerstones of the nascent and ever-evolving Brahmo theology.

When it comes to the idea of sahaja-jñanna, however, it can be said that Sen continued as an intellectual disciple and a successor of Tagore. Sen developed his idea of sahaja in his book, The Basis of Brahmoism, and claimed that "Brahmoism stands on the rock of intuition and is above the fluctuations of sectarian opinions. [And] intuition denotes those cognitions which our nature immediately apprehends-those truths which we perceive independently of reflection" (Sen 1900a, p. 55). He translates the words sahaja and sahaja-jñanna variously as innate idea, light of nature, or intuition, and in a later work called Jibana-Veda (Veda or Life), he claims that Vedic/Vedantic truths or any scriptural claim from any of the world's religions must be confirmed by one's own personal experience.

While ātma-pratyaya and sahaja-jñāna were both a part of Tagore's personal intellectual evolution as reflected in the development of the Brahmo Samaj, Sen joined the movement at a point when the idea of innate intuition was already a cornerstone of its epistemology. His perspectives on the evolution of the idea of sahaja-jñāna are thus not as dramatic as those of Tagore, and he did not develop them significantly enough to challenge the members of the Brahmo Samaj, regardless of faction. Note that neither Tagore nor Sen were trained theologians or philosophers, so their development of the ideas surrounding sahaja-jñāna appear to be piecemeal and haphazard, developing in response to the discourses happening around them. While Roy had undertaken all his intellectual experiments before deciding to initiate the Brahmo Sabhā, both Tagore and Sen had joined the movement during their early youth and rose to the top ranks while still relatively young. Their own personal intellectual developments, thus, were not confined to themselves, but were reflected in the collective consciousness of their movements. Their 'discoveries' of 'new' ideas steered the discourse of their entire movement, often fomenting unrest and confusion among their followers.

By the time Sen's theology evolved into the 'New Dispensation', the eclecticism in his system brought together disparate elements that might have seemed contradictory to a theologian of a religious tradition or a trained philosopher. But eclecticism, as Hatcher notes, is integral to Indic traditions, and colonialism happens to be the 'determinative condition' that gives rise to such eclecticism (Hatcher 1999, pp. 71-94). After all, theories, narratives, or metaphysical claims that might appear mismatched to Western sensibilities often seem congruous to Indian ones. Echoing Doniger's 'toolbox approach" to the interpretation of myths, Hatcher notes that "it is by no means uncommon for the Indian villager to seek the assistance of specialists working in as many as four different medical traditions: a little Ayurveda here, a little Unani there, some homeopathy today, a little allopathy tomorrow" (Hatcher 1999, p. 73). Sen, more than Tagore, adopted this process in his exploration of the various religions of the world and applied it to the theologies and rituals he came across. The basis of his eclecticism, however, was sahaja-jñāna.

In 1860, about 12 years after Tagore settled on the idea of intuition rather than Upanișadic testimony as the cornerstone of the Brahmo faith, Sen reasserted that Brahmoism "stands upon the rock of intuition and is above the fluctuations of sectarian opinions". He elaborated that "Brahmoism rests on no written revelation; neither does it hang on the opinions of particular persons or communities. It depends not upon the fugitive phenomena incident to age and country. It is in the basis of human nature ... It is founded on those principles which are above, anterior to, and independent of reflection-which the variation of opinion cannot alter or affect. It stands upon intuitions [which are] those cognitions that our nature immediately apprehends" (Sen 1900a, p. 40). I would argue that though Sen does not 
appear to move away from the sahaja-jñāna of Tagore, in reality, he does. Tagore rejected Upaniṣads as the basis of Brahmoism because of what he observed to be contradictions to his or Roy's sense of theism, but he never fully abjured them. He did not refer to the Bible, Qur'an, or the Tripitakas to form his Brāhmadharma, which he introduced as the canon of Brahmoism, to his followers. All of the passages in that book refer only to the Upanișads, and the quotes were arranged in a way that reflected the 'dualistic theism' of Tagore and attempted to shy away from any references to the monism of Śamkara.

The other major difference between Tagore and Sen is that Tagore formed the 'seed' of Brahmoism (brāhmadharmabijja) in the form of three axiomatic principles that stem from sahaja-jñanna. Sen never articulated any such axiomatic principles but rather elaborated on the meaning of the term in his essays and lectures. After writing The Basis of Brahmoism, Sen went on to pen a second set of essays in two parts, Testomonies to the Validity of Intuitions, arguing that "true philosophy rests on the pedestal of intuitions-its object being simply the legitimate exposition and application of the native cognitions of the mind" (Sen 1900b, pp. 78-93). To persuade his audiences, Sen quotes liberally from Aristotle, John Locke, Edward Herbert, Gottfried Leibnitz, David Hume, Samuel Taylor Coleridge, Victor Cousin, J. D. Morell, and John Tulloch, among others-but there is barely any mention of the Upanișads, Vedic R̦sis, or anything else from the Hindu tradition. In this effort, rather than situating the discussion of Brahmo epistemology within the intellectual discourse of India, Sen seems to have attempted an intervention in the history of philosophy itself, as Europeans understood it.

Notwithstanding the diversity of Western philosophers that he quotes, Sen attempts to establish that, even when a philosopher or a school of thought asserts any other epistemological mode, the unacknowledged basis continues to be intuition. Though many 'thoroughly ignore this intuitive or a priori element in human knowledge ... and regard this as capricious sentimentality or at best a derivative cognition,' Sen claims, for 'those who have studied the history of philosophy ... nothing is more certain than such a principle in the mind as Intuition' (Sen 1900b, p. 79). In this sense, intuition is not something that arises in a 'pure heart' as Tagore claimed, nor is it limited to the experience of Brahman. It is the basis of all cognition and thus the key modus operandi of all philosophers, even if their philosophical systems wholly contradict each other.

Unlike Tagore, who never articulated the details of sahaja-jñāna beyond stating the three axioms, Sen attempted to add coherence to the theology of sahaja-jñanna in The Basis of Brahmoism. This led him to identify five distinct characteristics, namely: immediacy, spontaneity, universality, originality, and self-evidence (Sen 1900a, pp. 43-45). A critical and comparative analysis of these characteristics will make it evident that whereas Tagore explored Western philosophy and was perhaps influenced by it as some contemporary scholars have suggested, he was quite atavistic when it came to Western philosophers, unlike Sen. The five characteristics of intuition that Sen presents in The Basis of Brahmoism appear to be his own articulation, although here too he makes liberal use of Western philosophers to bolster his argument while making no reference to anything from Hindu scriptural traditions.

The first characteristic of intuition is immediacy, in the sense that it is unmediated knowledge, which is "directly cognizable; it is seen face to face" (Sen 1900b, p. 43). Such an intuitive understanding of phenomena such as "cause, substance, power, infinite, duty" is thus not dependent on 'reflection', which primarily implies the rational cognitive process (p. 43). The next characteristic of intuition is spontaneity, in the sense that one perceives intuitive truths innately, as "they spring forth outright from our nature". Just as no amount of reasoning can lead to the immediacy of innate intuitions, the spontaneous nature of such intuitions does not "depend on the fiat of our volitions" (p. 43). The third characteristic of intuition is its universality, in the sense that such innate intuition applies to all human beings across time and space, at least according to Sen. For him "intuitive truths are facts of our nature and are independent of our will ... They are in possession of the wise and the illiterate-of the rich and the poor" (p. 44). The fourth feature of intuition is originality, as they are "not inferences on certain premises". They are 'primitive truths' in the sense that "they furnish materials for reasoning and scientific reflection-themselves underived and primitive" (p. 44). And the final, fifth aspect of 
intuition is that these truths are self-evident in the sense that "they are axiomatic truths which do not admit of demonstrations". Because of these characteristics, Sen concludes that "intuitions have been termed a priori, Truth, Axioms, Faith" (p. 44).

Sen's articulation of intuition makes frequent references to 'common sense' and 'primitive cognitions' that are reminiscent of the Scottish philosophical school of common sense. In his Testimonies essay he quotes Dugalt Stewart, Thomas Reid, and William Hamilton quite liberally, adopted almost the same kind of reverence with which Tagore would cite passages from the Upanisads. It is evident that Sen's essays thoroughly borrow from Reid's Essays on the Intellectual Powers of Man (Reid 1852) in articulating his Brahmo theology, but a detailed analysis of his sources would be a digression from our main focus, sahaja-jñāna. Sen's claim is that both Hume and Locke 'have been betrayed into the admission of [intuition's] validity,' (Sen 1900b, p. 79) and in a sense, this is correct: they both admit the validity of intuition as it relates to ideas. There is a distinction worth making here-Sen is making metaphysical claims, whereas Hume is often regarded as being anti-metaphysics and, along with Locke, does not seem to make claims about anything other than abstractions with the faculty of intuition. However, there is some confusion about seemingly contradictory claims, especially with Hume. Sen seems to be suggesting that Hume and Locke both admit the validity of intuition as it relates to metaphysics or ontology, but this is based on ambiguous statements rather than a systematic understanding of their philosophy.

\section{Bhaktivinoda's Sahaja-jñāna and Sahaja-samādhi}

While Tagore was very clear about his break from the Vedic and Upanișadic tradition, and Sen was open about sahaja-jñanna being his personal realization, Bhaktivinoda claimed to be in line with the Vedantic hermeneutics of his tradition. Bhaktivinoda's works were particularly grounded in the textual tradition of Caitanya Vaiṣnavism and rely heavily on the pre-colonial Sanskrit and Bengali sources in his religious and literary output. Some key sections of his books, such as the Datta Kaustubha (1873) and Krṣna Samhita (1879), adopt non-traditional epistemologies and hermeneutic modes in reading traditional texts. In particular, the method he calls 'adhunika-vāda' -literally, the 'contemporary method'-applies the historical critical method to traditional texts like the Bhāgavatapurāna and Māhäbhārata. These are also the texts where he mentions the term sahaja-jñanna for the very first time and develops the idea of sahaja-samādhi. These two related terms are quite alien to Vaiṣnavism, though he was presenting them in the Vaisnnava Vedāntic context as a part of the Sanskritic tradition.

Shukavak Dasa correctly noted in Hindu Encounter with Modernity that the term sahaja-samädhi "is not an expression commonly used within Chaitanya Vaiṣnava theology, or Hindu theology in general" and that "Bhaktivinoda's reliance on sahaja-samādhi as a genuine process of spiritual knowledge is a distinctive feature of his theological system" (Dasa 1999, pp. 155-56). He is also accurate when he says that sahaja-jñāna and samādhi aren't mentioned in the most exhaustive extant Vaiṣnava encyclopedia, the Gaudìya Vaiṣnava Abhidhāna (Das 1956), nor does this terminology ever appear in Vaișnava Sanskritic intellectual discourses, whether written or oral. Interestingly, despite summarizing the theology of sahaja-samādhi from the Bengali and Sanskrit works of Bhaktivinoda, Dasa does not mention the concept of sahaja-jñanna even once, though it is an equally important aspect of Bhaktivinoda's systematic theology. Dasa's assessment of sahaja-samādhi without an analysis of sahaja-jñāna leaves it undeveloped, and my article addresses this gap.

I further contend that Dasa's argument, "Bhaktivinoda's sahaja-samādhi is likely the result of [Rev. Charles] Dall's Unitarian efforts in Calcutta," is problematic in explaining the development of this key epistemological idea. Bhaktivinoda surely owes a debt of intellectual gratitude to Charles Dall that he acknowledges throughout his autobiography (Bhaktivinoda 1896), and he mentions how, during his youth, "a volume of Channing, Parker, Emerson or Newman had more weight than the whole lots of Vaishnava works" (Bhaktivinoda 1999, p. 378). However, we have seen so far that the intellectual history of the term before it appears in Bhaktivinoda's works is much more nuanced than what Dasa portrays it to be. 
As discussed earlier in this article, by the time Sen and Bhaktivinoda were active religious leaders, many agents of colonialism - evangelists, Orientalists, and British administrators in India—criticized Hinduism for polytheism, idolatry, promiscuity, and other perceived flaws, and examples of such 'deviant' religiosity included tantric sexual practices that pre-colonial sahaja-sādhana espoused. Considering such criticism, the term sahaja saw a distinct semantic shift in Bhaktivinoda's works, reflective of the educated middle-class Hindus distancing themselves from any practices that ran contrary to the norms of social respectability. Thus, despite the long history of sahaja within certain tantric Buddhist and Vaiṣnava communities, Sen and Bhaktivinoda's interpretations of sahaja dissociated any elements of secrecy or sexuality, especially any references to sexo-yogic practices. They both presented sahaja in a universal way, as 'innate intuition' that is natural to all living beings.

Despite theological differences between Sen, Bhaktivinoda, and their respective interpretations of sahaja, both attempted to arrogate this popular term and universalize it through Brahmo and Vaiṣnava theistic lenses. While Sen's theology claimed that divinity was ultimately attribute-less, Bhaktivinoda's brand of theism focused exclusively on Kṛnna as the supreme entity. Further, Sen completely effaced any sexual references of sahaja in his works, whereas Bhaktivinoda acknowledged a non-physical, psycho-erotic form of knowledge and practice available only to advanced initiates (Ghosh 2013). Neither, however, used the term sahajiya in any shape or form to describe themselves, perhaps because of the social stigma that educated middle-class Hindus held toward the religio-sexual practices of the sahajiyās.

Unlike Tagore and Sen, Bhaktivinoda developed a complex systematic theology of sahaja and suggested that sahaja-samadhi is jaiva-dharma, the natural function of the self (ātman). One of the primary arguments of Tattvaviveka (where he expounded his neo-sahaja theology) is that the ultimate concern of any philosophy, no matter which part of the world it comes from, is to answer existential questions pertaining to human suffering. Debating epistemology or discerning the true ontological nature of the phenomenal world was, after all, subsidiary to this existential quest. He began Tattvaviveka by stating questions that he considered to be common to all philosophical schools. He wrote, "The embodied entity, being situated in knowledge, asks the self: Who am I? What is this world? What exactly is the relation between the two?". For Bhaktivinoda, the answers to these questions have two epistemic modes: the rational mode that professional philosophers adopt, and 'sahaja', an intuitive mose that stems from 'consciousness'. When a jiva, the living being, tries to answer these questions only through philosophical or speculative reasoning, she comes up with what Bhaktivinoda calls 'citram uttaram' - a variety of partially correct answers. But when the jiva is sva-svarupa-sthita, or established in her own true nature, then no matter which part of the world she is in or how different the temporal, spatial, or cultural contexts might be, she has one true answer, a yuktam uttaram. Whatever else the word svarupa-sthita may mean in this context, the variety of answers that come from not being in one's own true nature forms the basis of his categorization of the world's philosophies.

This yuktam-uttaram that arises out of sahaja-jñāna is expressed in 12 axiomatic points, which for Bhaktivinoda are the foundational universal principles of spiritual life:

“(1) I am. (2) I continue to be. (3) Happiness is my nature. (4) My happiness comes from a certain place, a shelter, a source of that happiness. (5) It is natural for me to take [the] shelter of that reservoir of happiness. (6) I am an eternal seeker of that source of happiness. (7) That source of happiness must be very beautiful. (8) I have no power to abandon that source of happiness. (9) My present condition is lamentable. (10) Giving up my present suffering I should take [the] shelter of that source of happiness. (11) This material world is not my eternal home. (12) Material progression in this world will not benefit my eternal self." (Bhaktivinoda 1979, p. 29)

Bhaktivinoda's sahaja, or for that matter that of Tagore or Sen, have very little similarity to the pre-colonial version of sahaja-jñāna or samādhi of Vaiṣnava or Buddhist sahajiyās. If there was any secrecy in this modern avatar of sahaja theology, it was more akin to the secret knowledge of the âtman, 
or self, that is often hiding in plain sight, rather than the secrecy maintained around tantric sexual rites. The key point here is that while Sen's sahaja-jnana is a sense geared toward the worship of Brahman, Bhaktivinoda's leads to bhakti for Kṛ̣na. In the same text, Bhaktivinoda says that bhakti is sahaja-innate and universal. To prove his point, he explains that even though Buddhism promulgates emptiness, or sunyavāda, eventually any abstract philosophizing concedes to bhakti. He says:

"I once asked some questions to a Buddhist monk from Myanmar, a fellow who did not understand the true teachings of Buddhism. He answered my questions by saying, 'God is beginningless.' He created the entire world. Assuming the form of Buddha, He descended to this world and then, again assuming His form as God, He returned to heaven. If we act piously and follow the rules of religion, then we will go to His abode'. From what he told me, I could see that this Buddhist monk from Myanmar did not really study Buddhist philosophy. In the name of Buddhist philosophy, he simply repeated the basic tenets of his human nature as Buddhist philosophy. Philosophy based on tricks of logic cannot bring good to human society. Such tricky philosophy is cherished only in the hearts and books of professional philosophers. The people in general who claim to follow these philosophies will tend to revert to the intuitive sahaja ideas that are part of human nature." (Bhaktivinoda 1979, p. 15)

This dimension of Bhaktivinoda's sahaja-jñāna is quite similar to Sen's because both of them espouse the instinctive nature of the truths that an individual experiences in their spiritual journey. In this, both offer a similar perspective to the Scottish philosophers who proposed the idea of first truths, as discussed above. Sen stopped at the idea that the acknowledgment of ultimate being arises from innate intuition and is unmediated, spontaneous, self-evident, and universal. Bhaktivinoda goes a step further and claims that not only is the acknowledgment of God innately intuitive, but devotion to a transcendent deity is an intrinsic part of being human.

In fact, Bhaktivinoda develops a complete theology in which an individual progresses from an innate intuitive knowledge about transcendence to a state of 'experiencing' that transcendence, particularly in the form of Kṛnna. It is important to remember that Kṛṣna is not a Hindu deity for Bhaktivinoda, nor is he a historical figure from India, or a mythical character that appears in Indian epics. Rather, Kṛ̣na is a seeker's experience of the personhood of divinity that she encounters in a state of innate mystic rapture, samādhi. Bhaktivinoda charts these levels of progression in his Datta Kausubha (see Table 1), summarizing the Vedantic theology of his school and infusing it with the terms sahaja-jūāna and sahaja-samāahi (Bhaktivinoda 1942, p. 15).

Table 1. States of Samādhi, or Innate Mystic Rapture.

\begin{tabular}{|c|c|c|}
\hline $\begin{array}{l}\text { Sādhana } \\
\text { (Process) }\end{array}$ & $\begin{array}{c}\bar{A} \text { śraya } \\
\text { (Recourse) }\end{array}$ & $\begin{array}{c}\text { Sādhya } \\
\text { (Objective) }\end{array}$ \\
\hline \multicolumn{3}{|c|}{ Gauña Samadhi } \\
\hline sāṃkhya-jūāna-samādhi & Brahman & prapañca nivṛtti \\
\hline $\bar{a} t m a-j \tilde{n} \bar{a} n a-s a m \bar{a} d h i$ & paramātman & ātma-gata-kșudrānanda \\
\hline jñāna-miśra-sahaja-samāadhi & bhagavān & kiñcid-dvaitānanda \\
\hline \multicolumn{3}{|c|}{ Sāk șāt-samāadhi } \\
\hline $\begin{array}{l}\text { sahaja-samādhi } \\
\text { (Innate intuition) }\end{array}$ & $\begin{array}{l}\text { nāāāyaṇa } \\
\text { (realization of Nārāyaṇa as the supreme being) }\end{array}$ & aiśvarya-svarūpananda \\
\hline nitānta-sahaja-samādhi & krșna & mādhurya-svarūpānanda \\
\hline
\end{tabular}

Table 1 illustrates the most detailed version of a constructive systematic theology of sahaja-jñāna and sahaja-samādhi, in which Bhaktivinoda Vedanticizes the idea of intuition and brings the theology of the Gosvāmins of Brindavan into conversation with the intellectual developments of his own time. At the root of the chart is a key hermeneutical verse from the Bhāgavatapurāna (1.2.11) which says, 
"Those who know real truth (tattva) speak about that non-dual truth as Brahman (basis of existence), paramātman (the ultimate self, present everywhere), and bhagavān (the supreme entity)".

The details of Gaudiya Vaiṣnava theology are beyond the scope of this article, but the commentaries on this verse suggest that there are stages of realizing transcendental realities. The first stage of Brahman realization is to see divinity win the natural world, where the mountains are the bones of the divine, the rivers are his nerves, the oceans his belly, the clouds his hair, and the sun and moon his eyes. In this sense, divinity is embedded in nature itself and is both transcendent and immanent. When the seeker goes beyond the level of Brahman, she realizes that consciousness is above matter-it is the self, qualitatively non-different from the supreme self. The supreme self is present everywhere in the form of paramātman, which the seeker realizes in the second stage of progress. Beyond these two realizations of Brahman and paramātman comes an understanding in which one perceives the personhood of the divine as bhagavān. According to the Bhägavatapurāna, though the three dimensions of the same divine are one, they appear to be distinct because of human consciousness. Enlightened beings speak about them as if they are different, though they realize the three to be one undivided truth.

The Bengali mystic Sri Ramakrishna, a contemporary of Bhaktivinoda, explained it as follows: Though vapor, water, and ice happen to be the same substance, depending on the situation it finds itself in, it appears to be gaseous, liquid, or solid. Similarly, the divine happens to be one, no matter how individuals perceive it. This is be the basis of Hindu perennialism and neo-Vedāntic universalism.

For Bhaktivinoda, samādhi, when attained through the process of knowledge (sāmkhya) and analysis (jñāna), leads to the realization of Brahman, while samādhi through knowledge about one's real self (ātman) offers the experience of paramātman. While the realization of Brahman leads to emancipation from worldly suffering due to the removal of nescience, or avidy $\bar{a}$, realization of paramātman leads to a small amount of bliss that is inherent in the self. The third stage, when one transcends the realization of Brahman or paramātman, is when sahaja-samādhi occurs. In the first two stages, the seeker is not aware of the personhood of divinity. It is only through sahaja-samādhi that she understands that the divine is ultimately a sentient being. This stage lies beyond a rational process, or even the process of meditative self-realization.

This theology is somewhat in line with the Vedāntic interpretation of the devotional schools of Hinduism that follow intellectual developments instated by Rāmānuja (1017-1137), Mādhva (1238-1317), Nimbarka (1162?-1200?), and the founder of Bhaktivinoda's own school of thought, Caitanya. However, none of the founders of these respective schools of devotional theology ever mention sahaja-samādhi in their literature. Bhaktivinoda, though, considers it a transition from jñāna to samādhi to gauna samādhi, or secondary samādhi. Though he does not follow the traditional progression mentioned in Patañjali's Yogasutras, in spirit it is in consonance with the idea that the perfection of samādhi comes from complete surrender (pranidhāna) to îśvara. For Bhaktivinoda, real samadhi, which is unmediated, or sākșāt, occurs with the realization of not just a personal dimension of divinity, but an understanding of Nārāyana as the supreme being, who, for him, is İśvara. The final stage of samādhi, which he calls nitānta-sahaja ('extremely innate'), is the realization of Kṛsna. This difference between Nārāyana and Kṛṣna might seem superfluous, as both are manifestations of Viṣnu in Hindu religious literatures, but it is of great importance when it comes to the aesthetic (rasa) theology of the tradition.

In the Gosvāmīn literature that was written after Caitanya, any understanding of the personhood of divinity 'tinged' with a sense of awe and reverence is inferior to familiarity, since intimacy triumphs any sense of 'mysterium tremendum et fascinans', in Rudolf Otto (1928)'s language. According to the Bhaktirasāmrtasindhu of Rūpa Gosvāmin, devotion toward Kṛṣna in the mood of awe and reverence is inferior to an attitude of familiarity (Haberman 2003). After all, in the Bhāgavatapurāna, the stories suggest that Kṛ̣na's mother chases him for stealing butter. His friends play with him without a tinge of reverence, and the girls who fall in love with him do not treat him like God. This intimacy is something that even Nārāyana lacks, and thus Caitanya is supposed to have asserted that familiarity and intimacy are better than worship. To understand Kṛ̣na as God, the devotee must forget that Kṛ̣na is God. 
This theology when Bhaktivinoda says that one cannot understand Kṛṣa as the supreme being unless the disposition of the devotee is in the ultimate form of sahaja-samadhi. To be able to understand Kṛṣna, samādhi has to be free from any tinge of jñāna, and only when sahaja-samādhi is thoroughly simple can one experience the bliss of oneself in what some scholars have translated as 'aesthetic rapture' (Masson et al. 1970). In Caitanya's tradition, the highest goal of the spiritual process is not freedom from suffering, as it is in other Indian philosophical schools of thought—rather, freedom from suffering is seen as a side effect of aesthetic rapture. When the worshipper immerses herself in the plays of Kṛ̣na, even the Hindu goal of mokṣa, or liberation, becomes relatively insignificant. After all, when one experiences bliss, peace becomes somewhat inconsequential.

As I have argued elsewhere (Ghosh 2013), Bhaktivinoda is one of the bhadralok thinkers of the so-called Bengal Renaissance who does not completely efface the erotic dimensions of this important Hindu tradition, unlike his contemporaries Chatterjee, the father of Indian nationalism, or Roy, the father of modern India. However, in his discussions of sahaja-samadhi, Bhaktivinoda never invokes the erotic element, though it appears in many other parts of his written corpus. In particular, Dattakaustubha attempts to bring together a key element of popular religious discourse in Bengal and fuses it with a classical, pre-colonial, Chaitanya Vaiṣnava theology by evoking Bhāgavatapurāna (1.2.11) (see Table 1). In this way, he Vedānticizes sahaja-jñāna and samadhi. The Bhāgavatapurāna is considered to be a 'natural commentary' on the Vedānta Sūtras within Vaiṣnava intellectual circles. Though their understanding of Vedānta is very different from that of the Brahmo Samaj, or classical Advaita Vedānta, it is not difficult to encompass divergent interpretations under the larger rubric of Vedānta from the perspective of the social history of Indian philosophy.

Note that Bhaktivinoda uses a term that is popular among the so-called heterodox schools of Vaiṣnavism. In fact, across his written corpus, we find critiques of the sahajiyās as one of the 'deviant sects' (apasampradāyas). We have noted earlier in this article how the sahajiyās deploy the terms sahaja-jñanna and sahaja-samādhi to describe esoteric knowledge and sexo-yogic practices. Sexual connotations in Bhaktivinoda's treatment of sahaja are conspicuous in their absence, and in this he finds common ground with Sen's and Tagore's approaches. It is quite clear that Bhaktivinoda not only arrogates a term that he says belongs to the heterodox schools of Vaiṣnavism, but Vedanticizes it from a Sanskritic devotional perspective based on the theological canons of his tradition.

\section{Conclusions: Afterlife of a Religious Term}

The way the bhadralok religious leaders adopted the term sahajiya had very little to do with the proletariat use of the word, though their worlds seem to be colliding in the nineteenth century. This coming together of bhadralok religiosity and rural folk culture had a long, fraught path, but they converge as the nouveau-riche Bengalis of colonial India appeared to regain interest in 'folk culture'. But as we have seen, such adoption included arrogating, desexualizing, and Vedānticizing terms such as sahaja, sahajīy $\bar{a}$, sahaja-samādhi, and so on. This is significant in understanding the history of modern Hinduism because we see the process of 'churning' that takes place in the formation of epistemologies, social identities, and normative standards in popular culture. Individuals like Rammohan Roy, Keshub Sen, and Bankim Chandra Chatterjee are well known for shaping the discourse around religion, culture, and politics of modern India. Thus, their attitudes toward both the West and aspects of Indian culture that Western agents of colonialism despised provides rich story of the development of modern Hinduism. In particular, the intellectual experimentation with the concept and expression of sahaja-jñāna and samādhi might seem like a minor phase in the construction of modern Hinduism, but in actuality, the discourse about 'experience' as the basis of apprehending reality that Halbfass, Radhakrishnan, and many other contemporary thinkers describe has roots in this development.

Bhaktivinoda identified 13 groups that were flourishing in various parts of eastern India, which, in his understanding, were 'deviant'. These groups are termed $\bar{a} u l a, b \bar{a} u l a, k a r t a \bar{b} b a j \bar{a}$, nedā, daraveśa,

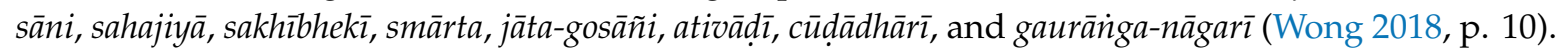
Note that the sahajīyas make it to this list as an apa—that is, deviant—sampradāya (school of a tradition). 
From Bhaktivinoda's perspective, the main idea behind so-called deviance is both sociological and theological, because membership in these groups apparently involved secret sexo-yogic practices that earned Vaiṣnavas social disrespect and were deemed unethical during the colonial period.

It is worth noting that many current-day followers of Bhaktivinoda, in both India and in the Western world, are completely oblivious to his interpretation of sahaja, sahaja-jnana, and sahaja-samadhi, perhaps because most of these books have not yet been properly translated. Moreover, though Bhaktivinoda disapproved of sahajiyaism, he still recognized it as distinct school of thought with a defined theology. For contemporary followers of Bhaktivinoda, who are concentrated mostly in the International Society for Krishna Consciousness and the Gaudiya Math, an understanding of the complexity of sahajiya theology is generally absent, and the normative discourse within those circles convey sahajiyāism as 'taking things cheaply' or 'imitation, and not real'. Beyond these groups, many traditional Vaiṣnavas consider the lineage of Bhaktivinoda an apa-sampradāya because of his unconventional innovations, including sahaja-samādhi.

Funding: Early versions of this paper were presented at Midwest and National AAR meetings between 2017-2018 which was supported by the Center for Scholarly and Creative Excellence, Grand Valley State University.

Acknowledgments: I would like to thank my students Leigh Anne Menard, Michael Snider, and especially Rylee Prach from Grand Valley State University, and Waverly Sisson from University of Oxford, UK who helped collect and review secondary materials around my research questions and read drafts of this paper. My editor Theresa Rothschadl and the highly efficient staff at Religions, especially Kate Yang and Bingjin He, deserves thanks for proofreading and preparing this manuscript before final publication. I would also like to thank the four anonymous reviewers for their helpful suggestions, and my colleagues in the Religious Studies Program and the Liberal Studies Department, specially Melanie Shell Weiss, Brent Smith, Wendy Burns Ardolino, Sarah King, and Azfar Hussain for their kind support and encouragement while I worked on this article. A big thank you to Sudipta Munsi, Institute for the Cultural and Intellectual History of Asia, Austrian Academy of Sciences, Vienna for being a friend and discussion partner who helped with the pratibhā section of the paper.

Conflicts of Interest: The author declares no conflict of interest.

\section{References}

Bādarāyaṇa, Śankkarācārya, and Swami Vireswarananda. 1936. Brahma-Sutras: With Text, Word-for-Word Translation, English Rendering, Comments According to the Commentary of Śrī Śankara, and Index. Almora: Advaita Ashrama.

Bhaktivinoda, Kedarnath Datta. 1896. Svalikhita Jìvani. Birnagar: Lalita Prasad Dutt.

Bhaktivinoda, Kedar Nath. 1942. Dattakaustubham. Dhaka: Sri Ramkrishna Pal.

Bhaktivinoda, Ṭākura. 1979. Tattva Viveka, vā Saccidānandanubhūtih. Kolkata: Baghbazar Gaudiya Math.

Bhaktivinoda, Kedar Nath. 1999. The Bhågavata, Ethics Its Philosophy, Its Ethics, and Its Theology. In Hindu Encounter with Modernity. Los Angeles: Sanskrit Reserch Institute, pp. 375-95.

Biswas, Sailendra. 2004. Samsada Bangala Abhidhana, 7th ed. Dictionary. Available online: http://dsal.uchicago.edu/ dictionaries/biswas-bengali/ (accessed on 13 December 2018).

Bombay (Presidency) Supreme Court. 1862. Report of the Maharaj Libel Case: And of the Bhattia Conspiracy Case. Bombay: Bombay Gazette Press.

Bose, Manindra Mohan. 1930. The Post-Caitanya Sahajiā Cult of Bengal. Calcutta: The University of Calcutta.

Bose, Mandakranta, and Sarika Priyadarshini Bose. 2013. A Woman's Ramayana: Candrāvatī's Bengali Epic. London: Routledge.

Broomfield, John H. 1968. Elite Conflict in a Plural Society: Twentieth-Century Bengal. Berkeley: University of California Press.

Bryant, Edwin F. 2007. Krishna: A Sourcebook. New York: Oxford University Press.

Chakrabarti, Ajitkumar. 1916. Maharshi Debendranath Thakur. Kolkata: Jigyasha.

Chakrabarti, Ramakanta. 1985. Vaiṣnavism in Bengal, 1486-1900. Calcutta: Sanskrit Pustak Bhandar.

Chattapadhaya, Bankimchandra. 1886. Kṛșna-Caritra. Kolkata: Bangīya-Sāhitya-Parishat.

Damen, Frans L. 1983. Crisis and Religious Renewal in the Brahmo Samaj, 1860-1884: A Documentary Study of the Emergence of the 'New Dispensation' under Keshab Chandra Sen. Leuven: Dept. Oriëntalistiek, Katholieke Universiteit Leuven.

Das, Haridas. 1956. Śrīšrī Gaudīìa-Baishṇaba-Abhidhāna. Nabadwip: Haribol Kutir. 
Dasa, Shukavak. 1999. Hindu Encounter with Modernity: Kedarnath Datta Bhaktivinoda, Vaiṣnava Theologian. Los Angeles: SRI.

Dasgupta, Shashi Bhushan. 1957. Śrīrādhāra Kramabikāśa: Darśanēē Sāhityē. Calcutta: E. Mukhārji \& Kōm.

Dasgupta, Shashi Bhushan. 1962. Obscure Religious Cults. Calcutta: Firma K.L. Mukhopadhyay.

Dimock, Edward C. 1989. Līlā. History of Religions History of Religions 29: 159-73. [CrossRef]

Doniger, Wendy. 2009. The Hindus: An Alternative History. New York: Oxford University Press.

Duff, Alexander. 1839. India, and India Missions: Including Sketches of the Gigantic System of Hinduism, Both in Theory and Practice: Also Notices of Some of the Principal Agencies Employed in Conducting the Process of Indian Evangelization, Ec. Ec. Edinburgh: J. Johnstone.

Eliade, Mircea. 1990. Autobiography: Vol. 1: 1907-1937, Journey East, Journey West. Translated by Mac Linscott Ricketts. Chicago: University of Chicago Press.

Elms, Alan C. 2001. Apocryphal Freud: Sigmund Freud's Most Famous 'Quotations' and Their Actual Sources. The Annual of Psychoanalysis 29: 83-104.

Emerson, Ralph Waldo. 1918. The Complete Works of Ralph Waldo Emerson: Poems. Boston: Houghton Mifflin.

Eraut, Michael. 2000. Non-Formal Learning and Tacit Knowledge in Professional Work. British Journal of Educational Psychology 70: 112-36. [CrossRef]

Flood, Gavin D. 1996. An Introduction to Hinduism. New York: Cambridge University Press.

Ghosh, Abhishek. 2013. Rethinking Krishna's Eroticism: Nineteenth Century Attitudes and Bhaktivinode's Hermeneutical Strategies. In The Sociology of Religion in India: Past, Present and Future. Edited by Ruby Sain and Ferdinando Sardella. New Delhi: Abhijeet Publications.

Gosvāmi, Krṣṇadāsa Kavirāja, Edward C. Dimock, and Tony Kevin Stewart. 1999. Caitanya Caritāmṛta of Kṛ̣nadāsa Kavirāja: A Translation and Commentary. Cambridge: Harvard Oriental Series.

Haberman, David L. 1988. Acting as a Way of Salvation: A Study of Rāgānugā Bhakti Sādhana. New York: Oxford University Press.

David L. Haberman, trans. 2003, The Bhaktirasāmṛtasindhu of Rūpa Gosvāmīn. Delhi: Motilal Banarsidass.

Halbfass, Wilhelm. 1988. India and Europe: An Essay in Understanding. Albany: State University of New York Press.

Hatcher, Brian A. 1999. Eclecticism and Modern Hindu Discourse. New York: Oxford University Press.

Hatcher, Brian A. 2008. Bourgeois Hinduism, or the Faith of the Modern Vedantists: Rare Discourses from Early Colonial Bengal. New York: Oxford University Press.

Hein, Norvin. 1995. Lila. In The Gods at Play: Lila in South Asia. Edited by William Sturman Sax. New York: Oxford University Press, pp. 13-20.

Kaviraj, Gopinath. 1923. The Doctrine of Pratibhā in Indian Philosophy. Annals of the Bhandarkar Oriental Research Institute 5: 1-18.

Kaviraj, Gopinath. 1984. Aspects of Indian Thought. Calcutta: University of Burdwan.

Kopf, David. 1979. The Brahmo Samaj and the Shaping of the Modern Indian Mind. Princeton: Princeton University Press.

Kuanpoonpol, Priyawat. 1991. Pratibhā: The Concept of Intuition in the Philosophy of Abhinavagupta. Cambridge: Harvard University.

Lorea, Carola. 2018. 'I Am Afraid of Telling You This, Lest You'd Be Scared Shitless!': The Myth of Secrecy and the Study of the Esoteric Traditions of Bengal. Religions 9: 172. [CrossRef]

Masson, J. L., Jeffrey Moussaieff Masson, and M. V. Patwardhan. 1970. Aesthetic Rapture: The Rasādhyāya of the Nātyaśāstra. Maharashtra: Deccan College Postgraduate and Research Institute.

Okita, Kiyokazu. 2014. Hindu Theology in Early Modern South Asia: The Rise of Devotionalism and the Politics of Genealogy. Oxford: Oxford University Press.

Otto, Rudolf. 1928. The Idea of the Holy. Np. Ravenio Books.

Patañjali, and Swāmī Hariharānanda Āraṇya. 1963. Yoga Philosophy of Patañjali with Bhāsvatī. Translated by P. N. Mukerji. Calcutta: University of Calcutta.

Polanyi, Michael, and Mary Jo Nye. 2015. Personal Knowledge: Towards a Post-Critical Philosophy. Chicago: University of Chicago Press.

Radhakrishnan, S. 1960. The Brahma Sūtra: The Philosophy of Spiritual Life. London: Allen \& Unwin.

Radhakrishnan, S. 1962. The Hindu View of Life. New York: Macmillan.

Raghavan, V. 1948. Prayers, Praises and Psalms: Selections from the Vedas, Upanishads, Epics, Gita, Puranas, Agamas, Tantras, Kavyas \& the Writings of the Acharyas and Others. Madras: G. A. Natesan. 
Reid, Thomas. 1852. Essays on the Intellectual Powers of Man. Cambridge: J. Bartlett.

Roy, Rammohan. 1818. Goswamider Sahita Bicāra. In Granthābali. Kolkata: Bangiya Sahitya Parishad.

Roy, Rammohun. 1820. The Precepts of Jesus: The Guide to Peace and Happiness. London: Baptist Mission Press.

Roy, Raja Ram Mohun. 1885. The English Works of Raja Rammohun Roy. Edited by Jogendra Chunder Ghose. Calcutta: Oriental Press.

Sastri, Sibnath. 1974. History of the Brahmo Samaj, 2nd ed. Calcutta: Sadharan Brahmo Samaj.

Schweig, Graham M. 2005. Dance of Divine Love: the Rāsa Līlā of Krishna from the Bhāgavata Purāna, India's Classic Sacred Love Story. Princeton: Princeton University Press.

Shahidullah, Muhammad. 1974. Buddhist Mystic Songs: Oldest Bengali and Other Eastern Vernaculars. Dacca: Bangla Academy.

Sen, Keshub Chunder. 1900a. Basis of Brahmoism. In Essays: Theological and Ethical—Keshub Chunder Sen, 3rd ed. Calcutta: The Brahmo Tract Society, vol. II.

Sen, Keshub Chunder. 1900b. Testimonies to the Validity of Intuitions, Part I \& II. In Essays: Theological and Ethical-Keshub Chunder Sen, 3rd ed. Calcutta: The Brahmo Tract Society, vol. II, pp. 78-93.

Shastri, Haraprasad. 1916. Hajar Bacharer Purano Bangala Bhashay Bouddhagan O Doha (Haraprasad Shastri) [Bengali Buddhist Lyrics and Poetry from a Thousand Years Ago]. Kolkata: Bangiya Sahitya Parishad.

Tagore, Devendranath. 1916. Autobiography of Maharshi Devendranath Tagore. Translated by Satyendranath Tagore, and Indira Devi. London: Macmillan and Co.

Tagore, Debendranath. 2017. Brāmasamājera Pañcaviṃsati Parikṣita Vṛttānta. Kollata: Sadharan Brahmo Samaj.

Tattvabhushan, Sitanath. 1909. The Philosophy of Brahmaism: Expounded with Reference to Its History, Lectures Delivered before the Theological Society, Calcutta, in 1906-1907. Madras: Higginbotham \& Co.

Ṭhākura, Debendranātha. 1960. Ātmaj̄̄banī: Debendranātha Thākura, 4th ed. Edited by Satishchandra Chakrabarti. Kolkata: Viśvabhārati Granthālaya.

Vidyābhuṣaṇa, Baladeva. 1912. The Vedānta Śūtras of Bādarāyana with the Commentaries of Baladeva. Translated by Srisha Chandra Vasu. Sacred Books of the Hindus. Allahabad: Pạini Office, vol. 5.

Vidyābhuṣaṇa, Baladeva. 1942. Vedāntasyamantaka. Translated by Bala Krishna Goswami. Vrindavan: Dina Bandhu Dāsa.

Vyāsa, Śrīdharasvāmin, and Jagdish Lal Shastri. 1983. Śrīmadbhāgavatapurāṇam. New Delhi: Motīlāla Banārasīdāsa. Williams, Monier. 1979. A Sanskrit-English Dictionary. Oxford: OUP.

Wong, Lucian. 2018. Against Vaiṣnava Deviance: Brāhmạ̣ical and Bhadralok Alliance in Bengal. Religions 9: 57. [CrossRef] 